Article

\title{
Evaluation of Corrosion Protection Performance of New Polymer Composite Coatings on Carbon Steel in Acid Medium by Electrodeposition Methods
}

\author{
Florina Branzoi ${ }^{1, *}$, Adriana Băran ${ }^{2}$ and Simona Petrescu ${ }^{3}$ \\ 1 Electrochemistry and Corrosion Department, Romanian Academy, Institute of Physical Chemistry \\ "Ilie Murgulescu", 202 Splaiul Independenței, 060021 Bucharest, Romania \\ 2 Colloid Chemistry Department, Romanian Academy, Institute of Physical Chemistry "Ilie Murgulescu", \\ 202 Splaiul Independenței, 060021 Bucharest, Romania; abaran@icf.ro \\ 3 Oxide Compounds and Materials Science Department, Romanian Academy, Institute of Physical Chemistry \\ "Ilie Murgulescu", 202 Splaiul Independenței, 060021 Bucharest, Romania; spetrescu@icf.ro \\ * Correspondence: fbrinzoi@chimfiz.icf.ro
}

Citation: Branzoi, F.; Băran, A.; Petrescu, S. Evaluation of Corrosion Protection Performance of New Polymer Composite Coatings on Carbon Steel in Acid Medium by Electrodeposition Methods. Coatings 2021, 11, 903. https://doi.org/ 10.3390/coatings11080903

Academic Editor: Daniel de la Fuente

Received: 28 June 2021

Accepted: 24 July 2021

Published: 28 July 2021

Publisher's Note: MDPI stays neutral with regard to jurisdictional claims in published maps and institutional affiliations.

Copyright: (c) 2021 by the authors. Licensee MDPI, Basel, Switzerland. This article is an open access article distributed under the terms and conditions of the Creative Commons Attribution (CC BY) license (https:/ / creativecommons.org/licenses/by/ $4.0 /)$.

\begin{abstract}
In this research, electrodeposition procedure was utilized for the synthesis of a new composite polymer: $N$-methylpyrrole-Triton-X100/N,N,N-diethylaniline (NMPY-TRX100/NNDEA) used as a coating on carbon steel type OL 37 electrode for corrosion protection. The surfactant Triton-X100, a dopant ion utilized throughout the process of electropolymerization, had a significant impact on the corrosion protection of this composite by impeding the penetration of corrosive ions. PNMPY-TRX100/PNNDEA coatings were successfully realized on the OL37 substrate by a galvanostatic method of synthesis using the solutions 0.1 M NNDEA, 0.1 M MPY, 0.03 M TRX-100, and $0.3 \mathrm{M} \mathrm{H}_{2} \mathrm{C}_{2} \mathrm{O}_{4}$, at varied current densities $\left(3 \mathrm{~mA} / \mathrm{cm}^{2}, 5 \mathrm{~mA} / \mathrm{cm}^{2}\right.$ and $\left.8 \mathrm{~mA} / \mathrm{cm}^{2}\right)$ in different molar ratios (1:1, 1:5, 3:2 and 5:1). The deposition was performed for 20 and $30 \mathrm{~min}$. The polymeric composite coatings were characterized electrochemically, spectroscopically, and morphologically by cyclic voltammetry, Fourier transform infrared spectroscopy, and scanning electron microscopy methods. Corrosion protection performance of PNMPY-TRX100/PNNDEA-coated OL 37 was examined through potentiostatic and potentiodynamic polarization, open circuit potential measurements, and electrochemical impedance spectroscopy procedures in $0.5 \mathrm{M} \mathrm{H}_{2} \mathrm{SO}_{4}$ media. The corrosion rate of PNPMPY-TRX100/PNNDEA-coated OL 37 was denoted to be around nine times less than that of an uncoated electrode. The corrosion protection yield of the coating was more than $90 \%$. The best effectiveness was realized for PNMPY-TRX-100/PNNDEA by electrodeposition at $5 \mathrm{~mA} / \mathrm{cm}^{2}$ current density applied in molar ratios of 5:1 and 3:2, and at $8 \mathrm{~mA} / \mathrm{cm}^{2}$ current densities applied in molar ratio 5:1. The outcomes of the corrosion experiments revealed that PNMPY-TRX-100/PNNDEA coatings provide a good anticorrosion protection of OL 37 in corrosive solutions.
\end{abstract}

Keywords: polymer; composite; electrodeposition; corrosion protection; SEM; EIS; FT-IR

\section{Introduction}

The electropolymerization of conducting polymers onto the active area of metals and its alloys has been a topic of research, mostly conforming to the anticorrosion protection results of experiments carried out on composite polymer coatings [1-6]. The performance of these protective coatings, which provide a barrier to the substrate, can be influenced by various factors: the type of conducting polymer, the electropolymerization method used on the electrode's surface, and the type of aggressive environment [7-11]. The application of electrochemical polymerization mechanism, nanostructured coatings, applying organic or inorganic coatings, and cathodic and anodic protection are methods for decreasing corrosion on metallic materials [12-17]. In recent years, there have been experiments on the employment of conducting polymer coatings over metallic materials for anticorrosion 
protection [18-22]. The metallic materials are used on a large scale in different industry practice, such as chemical manufacture, petroleum production and refining, technological equipment, and marine practices; this has aided the investigation into anticorrosion protection in varied corrosive environments [23-27]. Since corrosion is a substantial factor in the damage of industrial structures, a great number of experiments were achieved to find techniques to mitigate corrosion and wear cost. Sulfuric acid solutions are utilized in several manufacturing processes which generally lead to serious metallic corrosion of diverse metal structures and apparatuses in industrial settings. In addition, the rate of corrosion which the metals exhibit in an acidic environment is highly increased, particularly when soluble corrosion outcomes are achieved. The inquiry of carbon steel corrosion occurrences became important mainly in sulfuric acidic environments because of the increasing technological practicability of acid media.

Protection of these metals can be accomplished by many methods of which the organic coatings are frequently utilized to defend the metallic materials for corrosion. Much research realized for the protection of materials in the area of engineering has showed that using composite polymer coatings is the most efficient and simple mode of impeding deterioration of metallic materials in corrosive environments [28-32]. The electrochemical synthesis of new composites among various monomer molecules was observed to enhance the physico-chemical characteristics of polymer coatings, increasing protection time, enhancing adherence, and improving the electrochemical properties. However, by enhancing the electrodeposition of a polymeric composite, it is feasible to enhance the mechanical and protective features of the polymer to be used as an anticorrosive layer in varied aggressive environments. Several investigations were carried out on the use of protective layers for conducting and insulating estates of polymers on diverse materials [32-36]. Conducting polymers are attracting considerable interest as anticorrosion coatings for various metals and their alloys since the main activity of polymer coatings is to be a barrier for aggressive compounds. This property can be enhanced through the employment of organic composites in different fields of materials because they are easy to obtain and flexible to apply from a distance [32-36]. The electrochemical and physical features of polymers are affected by the type of dopant and electrolyte used in the polymerization mechanism [31-34]. In recent years, conducting polymers have attracted attention in scientific and technological areas according to their chemical, environmental, biological, electrical, thermal, and optical features, the ease of their acquirement, and their practicality. Conducting polymers are intriguing molecular compositions due their ability to modify characteristics when acted on by an electric signal [31-36]. These new materials yield significant potential for a wide range of new implementations as capacitors, sensor, solar cells, batteries, membranes, nanoelectronics, and corrosion protection coatings.

The objective of this paper is to find new conductive polymers suitable for corrosion protection of ordinary metals. In addition, we aim to develop proper electrochemical polymerization techniques that will give the ability to obtain dense, strongly adherent composite coatings onto metallic substrates. Another focus area is obtaining and optimizing new composite polymers with superior anticorrosion properties for some metals in corrosive media. These composite materials are different from those reported in the literature and performed better experimentally. The aim of this research is to investigate two various conducting polymers, firstly as coatings on electrode surface employment $N$-methylpyrrole (NMPY)-TritonX-100(TRX100) / N,N-diethylaniline (NNDEA). The new composite (PMPY-TRX100/PNNDEA) was subjected to electropolymerization on OL 37 substrate by galvanostatic technique by synthesis solutions of $0.1 \mathrm{M} \mathrm{N}$-methylpyrrole, $0.1 \mathrm{M} \mathrm{N}, \mathrm{N}$-diethylaniline, $0.03 \mathrm{M}$ Triton-X100, and $0.3 \mathrm{M}$ oxalic acid. Examination of the new composite coatings was realized by cyclic voltammetry, Fourier transform infrared (FT-IR) spectroscopy, and scanning electron microscopy (SEM) procedures. Corrosion comportment of PNMPY-TRX100/PNNDEA-coated OL 37 was considered by potentiodynamic polarization and electrochemical impedance spectroscopy (EIS) methods in $0.5 \mathrm{M}$ sulfuric acid solution. 


\section{Experimental}

All chemicals were reagent grade $\mathrm{N}, \mathrm{N}$-diethylaniline (NNDEA), $\mathrm{N}$-methylpyrrole (NMPY), and Triton X-100 (TRX-100), and were supply from Aldrich (98\%); acid oxalic dehydrate was acquired from Merck (97\%). In all measurements, the solutions were made by utilizing bidistilled water: NNDEA $0.1 \mathrm{M}$, TRX-100 $0.03 \mathrm{M}$, MPY $0.1 \mathrm{M}$ and oxalic acid $0.3 \mathrm{M}$. The chemical structure of working electrode type OL 37 was: C $0.15 \%$, Si $0.09 \%$, Mn $0.4 \%$, Fe $99.293 \%$, P $0.023 \%$, S 0.02\%, Al 0.022\%, Ni 0.001\%, and Cr $0.001 \%$. The electrochemical polymerization and characterization were accomplished by utilizing a single-compartment cell with the standard three electrodes set up at room temperature. The electrochemical cell was logged to a VoltaLab potentiostat coupled with a PC running VoltaMaster software (Lyon, France). A saturated calomel electrode (SCE) was used as a reference electrode and a platinum plate as an auxiliary electrode. The working specimen was a carbon steel OL 37 rod with a surface area of $0.5 \mathrm{~cm}^{2}$. A potentiostat VoltaLab PGZ 402 (Lyon, France) was used in all electrochemical measurements. The polymeric coating composition was performed by Bruker optics FT-IR spectrometer with ATR (Ettlingen, Germany) in the spectral domain $4000-650 \mathrm{~cm}^{-1}$ at a resolution of $4 \mathrm{~cm}^{-1}$. Samples morphology studies were carried out by scanning electron microscopy (SEM) in a dual beam FEI Quanta 3D FEG model (FEI, Brno, Czech Republic), operating in high vacuum mode with an accelerating voltage of 15 to $30 \mathrm{kV}$. Minimal samples preparation consisted of immobilizing the electrodes on a double-sided carbon tape, without coating. Before every measurement, the OL 37 electrode was burnished by a succession of emery papers of varied grades (250 up to 4000 ) up to a mirror sheen. Subsequent to polishing, the OL 37 electrode was rinsed with acetone and bidistilled water and dried at room temperature then entered into the electrochemical cell. Before electropolymerization of polymer coatings, the OL 37 working specimen was passivated in $0.3 \mathrm{M} \mathrm{H}_{2} \mathrm{C}_{2} \mathrm{O}_{4}$ solution by cyclic voltammetry on the domain potential of $-600 \mathrm{mV}$ up to $1200 \mathrm{mV}$ versus SCE at a potential scan rate $20 \mathrm{mV} / \mathrm{s}$. Each experiment test was repeated three times to check the reproducibility.

The poly ( $N$-methylpyrrole-Triton-X100/N,N-diethylaniline) coatings were synthesized by the electropolymerization of $0.1 \mathrm{M} \mathrm{N}$-methylpyrrole, $0.03 \mathrm{M}$ Triton-X100, $0.1 \mathrm{M}$ $\mathrm{N}, \mathrm{N}$-diethylanilineand $0.3 \mathrm{M}$ oxalic acid over OL 37 passivated electrode surface using galvanostatic experiment. The electrosynthesis was achieved by galvanostatic method at current densities $3 \mathrm{~mA} / \mathrm{cm}^{2}, 5 \mathrm{~mA} / \mathrm{cm}^{2}$, and $8 \mathrm{~mA} / \mathrm{cm}^{2}$ in different molar ratios $(1: 1$, 1:5, 3:2, and 5:1) and the deposition was permitted for 20 and $30 \mathrm{~min}$. The adherence of the coating was effectuated with the "standard Sellotape test", that involves cutting the film into small squares, sticking the tape, and then stripping it. The percent adherence was accomplished by considering the proportion of the number of the remaining adherent coating squares to the total number of the squares. The electroactivity of coatings was studied in $0.3 \mathrm{M} \mathrm{H}_{2} \mathrm{C}_{2} \mathrm{O}_{4}$ solution by cyclic voltammetry technique. The protection against corrosion of the coated electrodes was investigated by methods of potentiodynamic polarization and electrochemical impedance spectroscopy (EIS, Lyon, France) in $0.5 \mathrm{M} \mathrm{H}_{2} \mathrm{SO}_{4}$ solutions. Exploration of the Tafel polarization curves were performed through sweeping the potential with the cathodic to the anodic potential in the range of $-800 \mathrm{mV}$ to $-150 \mathrm{mV}$ (SCE) at a scan rate of $2 \mathrm{mV} / \mathrm{s}$ for the OL 37 working electrode. All potentials were recorded against the SCE. Electrochemical impedance spectroscopy measurements were performed in frequency intervals from $100 \mathrm{kHz}$ to $0.04 \mathrm{~Hz}$ with $10 \mathrm{mV}$ amplitude to an open circuit potential of PNMPY-TRX100/PNNDEA-coated and -uncoated electrodes. Presented below is the Scheme 1 of obtaining and characterizing polymeric composite electrodeposition on the OL 37 electrode surface (see Scheme 1). 


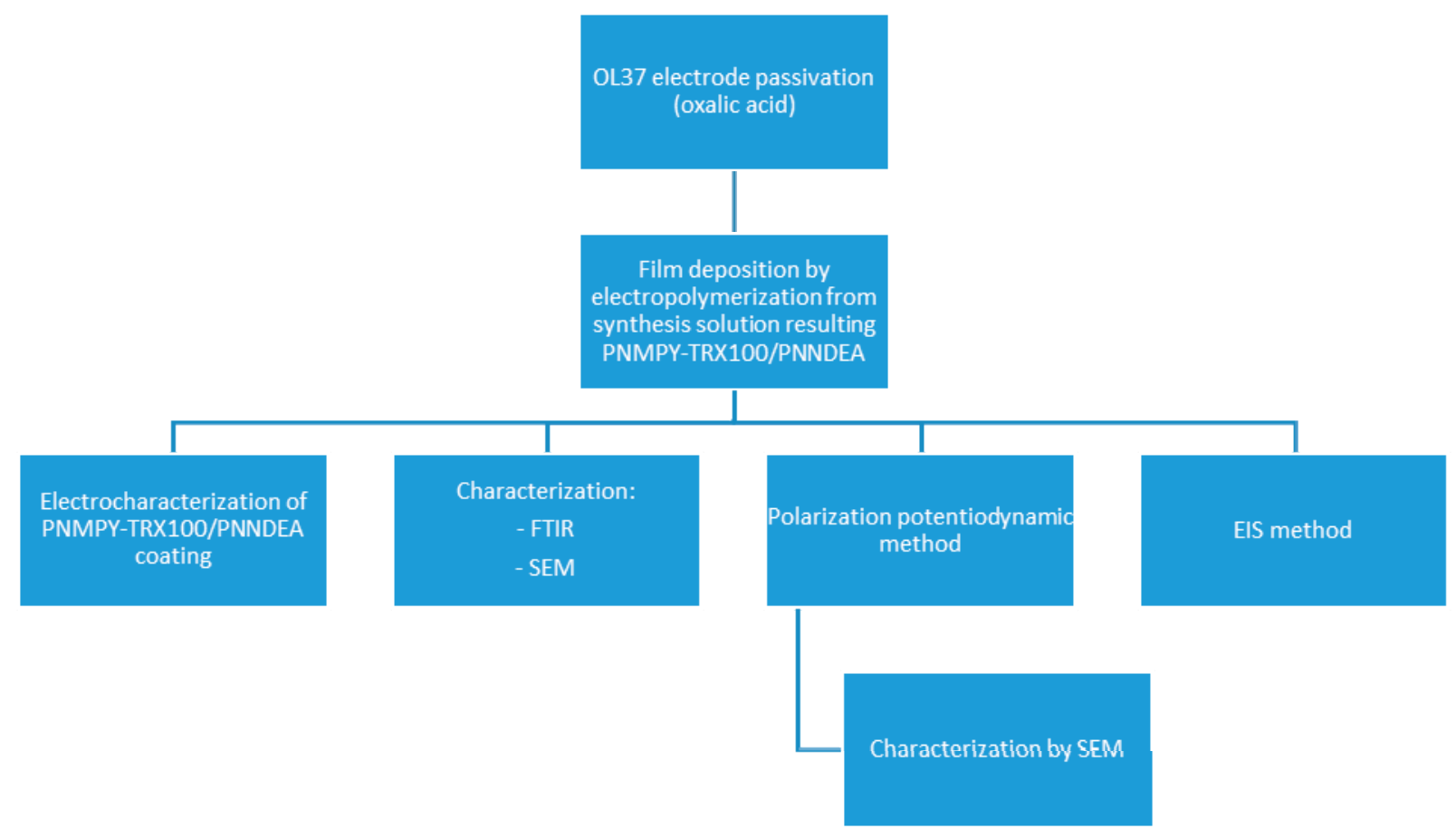

Scheme 1. Procedure for obtaining and characterizing polymeric composite electrodeposition on the OL 37 electrode surface.

\section{Results and Discussion}

\subsection{Electrodeposition PNMPY-TRX100/PNNDEA Coating on OL 37 Electrode}

Before obtaining PNMPY-TRX100/PNNDEA, the working electrodes OL 37 were initially polarized in a $0.3 \mathrm{M} \mathrm{H}_{2} \mathrm{C}_{2} \mathrm{O}_{4}$ solution by sweeping the potential electrode at. Intervals of $-600 \mathrm{mV}$ up to $+1200 \mathrm{mV}$ at scan rate $20 \mathrm{mV} / \mathrm{s}$. A considered electropolymerization requires the obtainment of a passive film, which could be effective to impede the dissolution of the oxidizable metal without blocking admission of the monomer and its subsequent oxidation. This procedure of OL 37 substrate passivated by the above electropolymerization method was also exhibited in literature [19-23]. The passivation procedure is accomplished by distributing the insoluble components over the OL 37 surface. These insoluble species obtained from the passivation mechanism contain iron oxides and iron oxalates such as $\mathrm{Fe}$ $\left(\mathrm{O}_{\mathrm{x}}\right)\left(\mathrm{FeO}, \mathrm{Fe}_{2} \mathrm{O}_{3}\right)$ and $\mathrm{FeC}_{2} \mathrm{O}_{4}$ which impede the dissolving of metal without stopping the electrodeposition mechanism. By improving the polymerization conditions, we can obtain polymeric films of PNMPY/PNNDEA that give protection from corrosion. Presented in Figure 1 are the cyclic voltammograms recorded to the passivation of OL 37 electrode in $0.3 \mathrm{M} \mathrm{H}_{2} \mathrm{C}_{2} \mathrm{O}_{4}$ solution.

As seen in Figure 1, the initial cycle on the anodic curve exhibits a wide oxidation peak at the potential $-203 \mathrm{mV}$ and with a peak current density of $18.49 \mathrm{~mA} / \mathrm{cm}^{2}$ which indicates that the dissolving of $\mathrm{Fe}$ is instituted, and that the dissolution mechanism is significant; this reaction results in $\mathrm{Fe}^{2+}$ ions. These ions $\left(\mathrm{Fe}^{2+}\right)$ operate with the electrolyte to create an insoluble iron oxalate $\left(\mathrm{FeC}_{2} \mathrm{O}_{4}\right)$ film onto the OL 37 surface. This passivated layer impedes dissolving without affecting the electropolymerization mechanism. The second anodic peak as a repassivation is noted at potential $108 \mathrm{mV}$ and at current density $55 \mathrm{~mA} / \mathrm{cm}^{2}$. This repassivation peak is attributed to the change of the passive film from iron (III) oxide and/or oxalates to iron (II) oxalate, as determined through the positive sweep. 

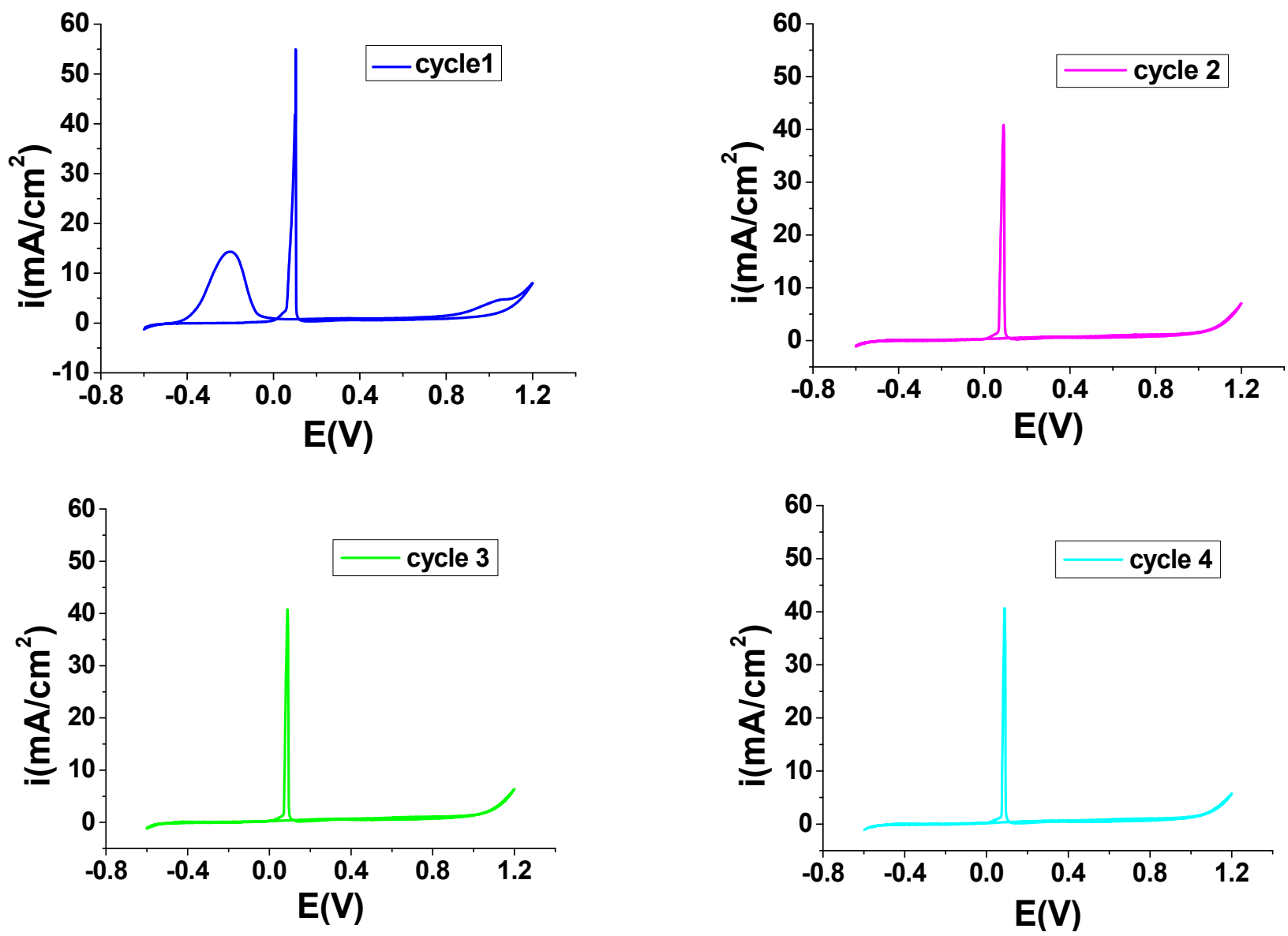

Figure 1. The voltammograms achieved at the polarization of OL 37 electrode in $0.3 \mathrm{M} \mathrm{H}_{2} \mathrm{C}_{2} \mathrm{O}_{4}$ solution on the potential range of -600 to $+1200 \mathrm{mV}$ at scan rate $20 \mathrm{mV} / \mathrm{s}$ at 4 cycles.

The electropolymerization of NNEA and NMPY monomers was performed on the surfaces of the passivated OL 37-like working electrode. Following passivation, the electropolymerization of monomers was initiated without modifying the polymerization characteristics. The polymeric composite PNMPY/PNNDEA was accomplished. The polymeric composite coatings were performed under galvanostatic conditions from $0.3 \mathrm{M} \mathrm{H}_{2} \mathrm{C}_{2} \mathrm{O}_{4}$, $0.1 \mathrm{M} \mathrm{N}, \mathrm{N}$-diethylaniline, $0.03 \mathrm{M}$ Triton $\mathrm{X} 100$, and $0.1 \mathrm{M}$ methylpyrrole at current densities $3 \mathrm{~mA} / \mathrm{cm}^{2}, 5 \mathrm{~mA} / \mathrm{cm}^{2}$, and $8 \mathrm{~mA} / \mathrm{cm}^{2}$, and the electrodeposition was permitted for $20 \mathrm{~min}$ and $30 \mathrm{~min}$. Figure 2 represent the "potential-time" curves obtained through the constitution of the polymeric film: composite polyN-methylpyrrole-triton X100/poly $\mathrm{N}, \mathrm{N}$-diethylaniline onto carbon steel OL 37 (PNMPY-TRX100/PNNDEA/OL 37) PPYAOT/PNEA at varied applied current densities in different molar ratios.

Subsequent to the oxidation period of $1200 \mathrm{~s}$ and $1800 \mathrm{~s}$, the initial shape of the "potential-time" curves during the polymer electropolymerization process indicates that the polymer deposition was done by nucleation and growth on the electrode surface [15-20]. It can be seen from Figure 2a,c that the lesser concentration for MPY and NNDEA increased the induction period (for molar ratio 5:1) of NMPY-TRX100: NNDEA, where induction time is less than $90 \mathrm{~s}$, and to higher concentrations for NMPY-TRX100: NNDEA the induction period is $30 \mathrm{~s}$. Yet, the potential remained steady at values appropriate to the monomer oxidation and the initiated electropolymerization procedure. 


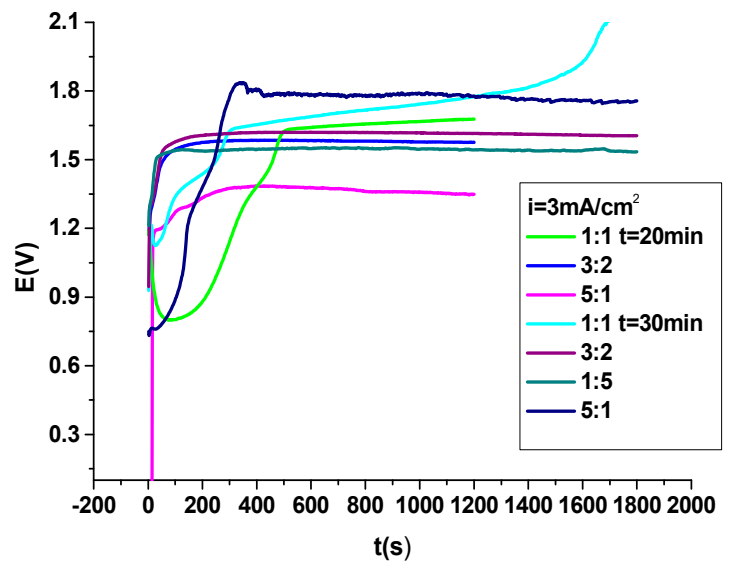

(a)

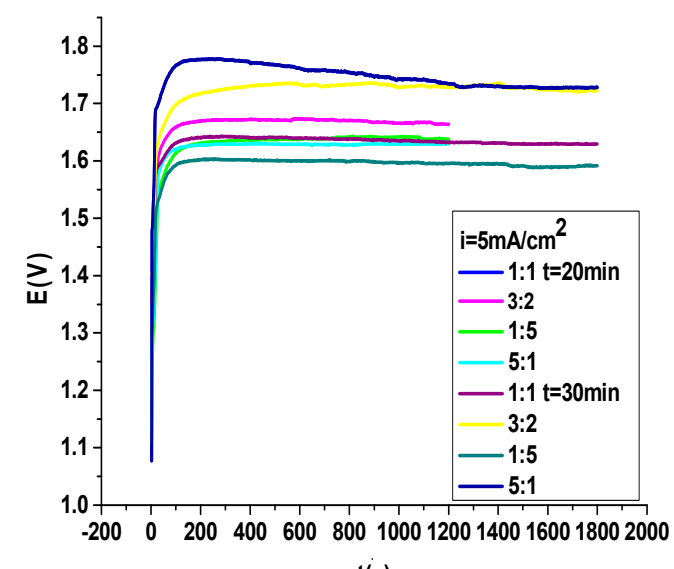

$t(s)$

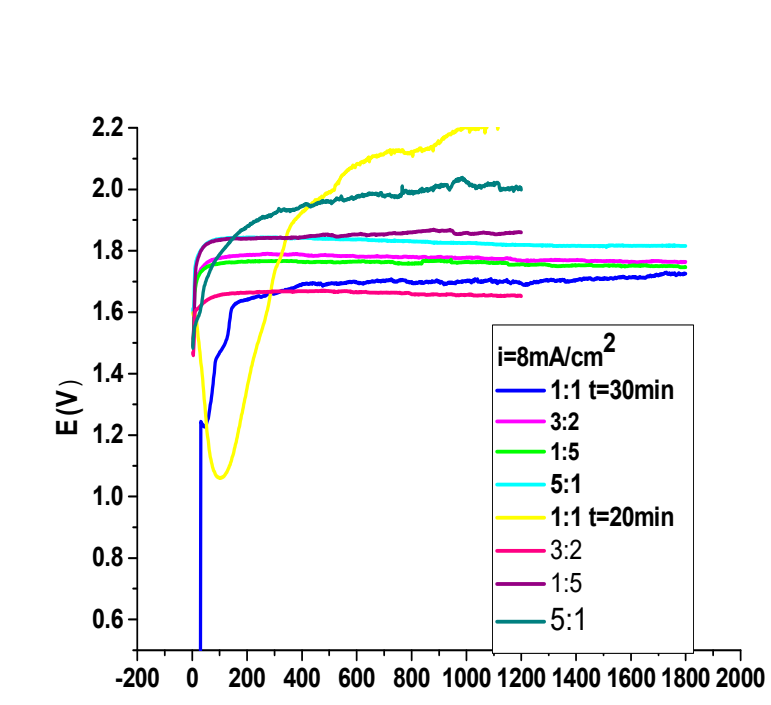

(b)

$\mathbf{t}(\mathbf{s})$

(c)

Figure 2. Galvanostatic method for obtaining of PNPY-TRX100/PNNDEA/OL 37 at current densities (a) $3 \mathrm{~mA} / \mathrm{cm}^{2}$, (b) at $5 \mathrm{~mA} / \mathrm{cm}^{2}$ and (c) at $8 \mathrm{~mA} / \mathrm{cm}^{2}$ ) and permitted for $20 \mathrm{~min}$ and $30 \mathrm{~min}$ at varied molar ratios for PNMPY-TRX100 and PNNDEA.

Figure $2 \mathrm{~b}$ shows how at $5 \mathrm{~mA} / \mathrm{cm}^{2}$ was applied to current densities at various molar ratios, it resulted in smaller induction periods, with induction ranges as low as $20 \mathrm{~s}$ noticed for the electropolymerization of NMPY and NNDEA composite layers, and their values lessened when molar ratios and nucleation potentials were increased. The polymerization potential was varied between $1.6 \mathrm{~V}, 1.7 \mathrm{~V}, 1.8 \mathrm{~V}$, and $2.1 \mathrm{~V}$ versus SCE for applied current densities: $3 \mathrm{~mA} / \mathrm{cm}^{2}, 5 \mathrm{~mA} / \mathrm{cm}^{2}$, and $8 \mathrm{~mA} / \mathrm{cm}^{2}$ in 1:1, 1:5, 3:2, and 5:1 molar ratios for NMPY-TRX100 and NNDEA. The surfactant TRX100 as a dopant ion utilized through electropolymerization (introduced in methylpyrrole) can have a meaningful effect on the ion modification selectivity assurance of polymer conductivity. The coatings obtained at applied current densities about $5 \mathrm{~mA} / \mathrm{cm}^{2}$ possess the most homogeneous and adherent appearance and were favorable for the formation of high-quality PNMPY-TRX-100/PNNDEA coatings. The visual observation of the OL 37 sample surface following deposition shows the forming of a black colored PNMPY-TRX-100/PNNDEA layer. The polymeric composite coating is uniform, compact, and adherent on the OL 37 electrode surface. The coating adherence assessed through "the standard Sellotape" was observed to be $\sim 82 \%$. 


\subsection{Electrocharacterization of PNMPY-TRX100/PNNDEA Coating}

The cyclic voltammograms of PNMPY-TRX100/PNNDEA-coated OL 37 electrodes in the monomer-free $0.3 \mathrm{M} \mathrm{H}_{2} \mathrm{C}_{2} \mathrm{O}_{4}$ medium are exhibited in Figure 3 by the potential range of -0.5 and $+1.5 \mathrm{~V}$ vs. SCE at a scan rate of $20 \mathrm{mV} / \mathrm{s}$.

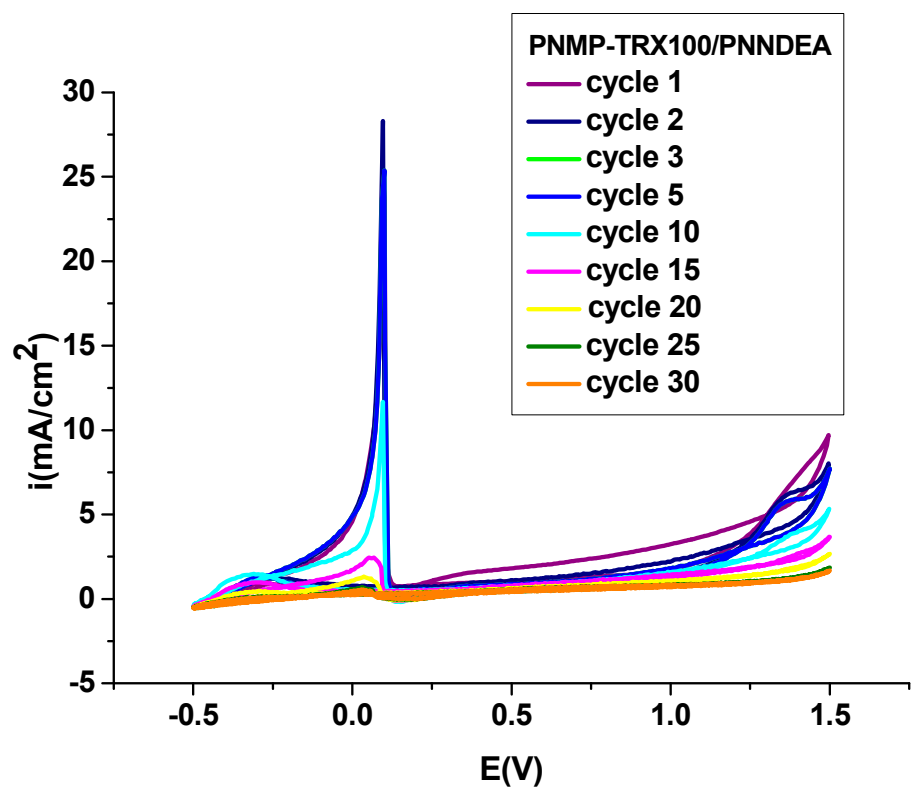

Figure 3. Cyclic voltammograms of OL 37 electrode coated with PNMPY-TRX-100/PNNDEA/OL 37 in $0.3 \mathrm{M} \mathrm{H}_{2} \mathrm{C}_{2} \mathrm{O}_{4}$ at a potential range -0.5 and $1.5 \mathrm{~V}$ vs. SCE and scan rate of $20 \mathrm{mV} / \mathrm{s}$.

The cyclic voltammograms of PNMPY-TRX-100/PNNDEA-coated OL 37 electrode in the monomer-free $0.3 \mathrm{M} \mathrm{H}_{2} \mathrm{C}_{2} \mathrm{O}_{4}$ medium are exhibited in Figure 3 in the potential range of -0.5 and $+1.5 \mathrm{~V}$ vs. SCE at a scan rate of $20 \mathrm{mV} / \mathrm{s}$. Figure 3 shows the electrochemical behavior of composite layer change in the succession of cycles and with electrodeposition conditions. The steadiness of either one conducting polymer in reduced and oxidized estates is a meaningful characteristic for various applications. The main cause which establishes the lifetime of a polymer is a chemical steadfastness of the matrix itself.

The steadfastness of PNMPY-TRX-100/PNNDEA/OL 37 polymeric composite coating was assessed by cyclic voltammetry in the oxalic acid medium (see Figure 3). Cyclic voltammetry was effected in the large potential domain to examine all the physical and electrochemical features of the composite films. The existence of oxidation and reduction wave, according to a lot of cycles (more than 25), demonstrated the steadiness of these electrochemical activity polymer layers [28-32,34]. When these films were cycled frequently among the oxidized and reduced form without important decomposition of the polymeric composite, the current density was reduced by every cycle and ultimately settled at a steady level [28-32,34].

\subsection{FT-IR Studies}

Fourier transform infrared (Figure 4) spectra were achieved with a Bruker optics spectrometer at room temperature. Every spectrum in this study was examined at a resolution $4 \mathrm{~cm}^{-1}$ in the spectral interval of $4000-650 \mathrm{~cm}^{-1}$. FT-IR method can be used to examine the kind of bonding taking place in a new polymeric composite. The specific peaks in the transmittance spectrum PNMPY-TRX-100/PNNDEA/OL 37 coatings are indicated in Figure 4. The FT-IR data expose the presence of the significant absorption bands remarked for PNMPY and PNNDEA deposited onto the OL 37 electrode. 


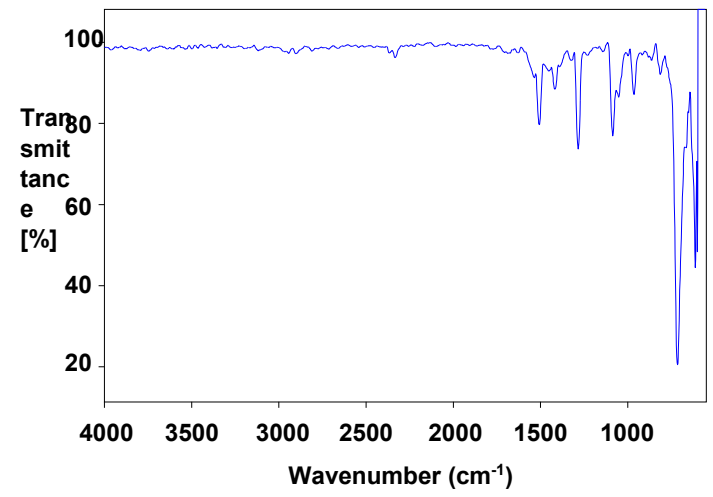

(a)

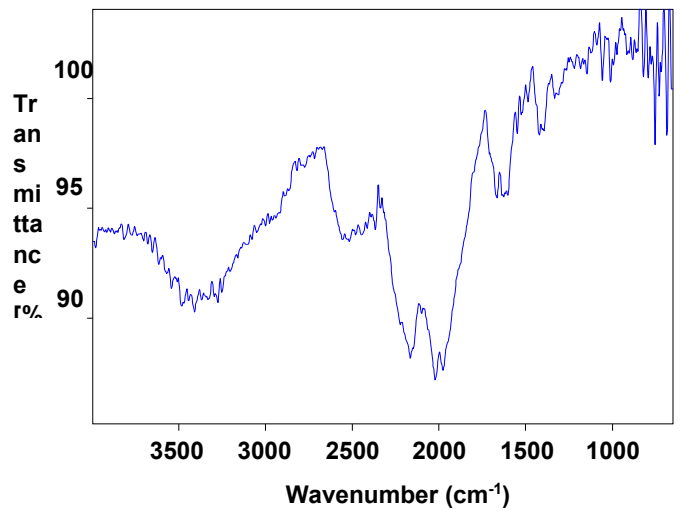

(c)

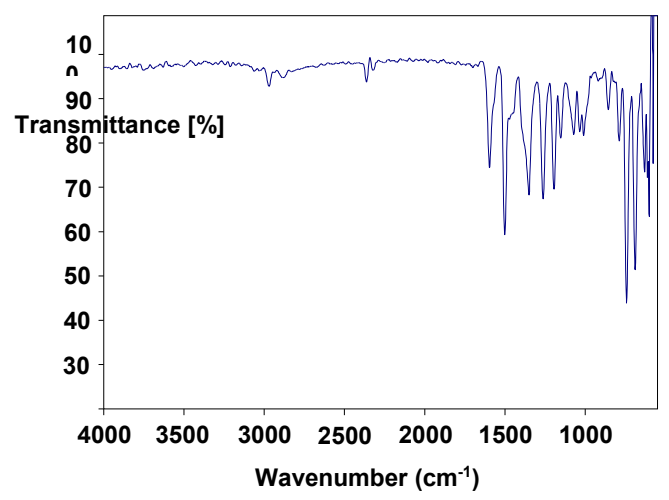

(b)

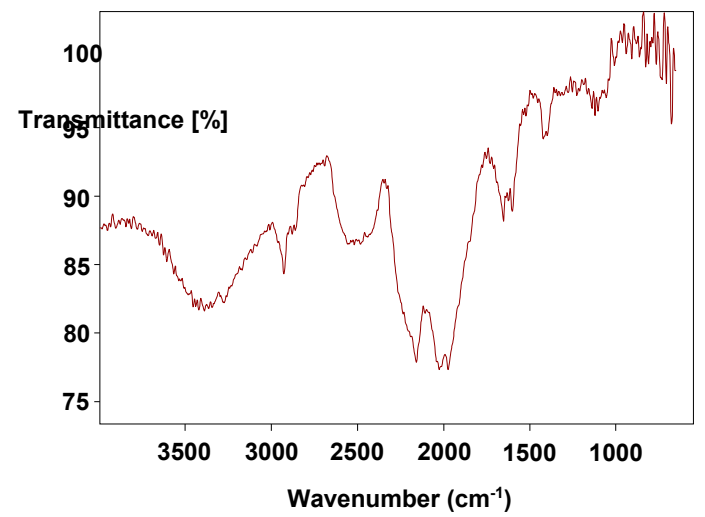

(d)

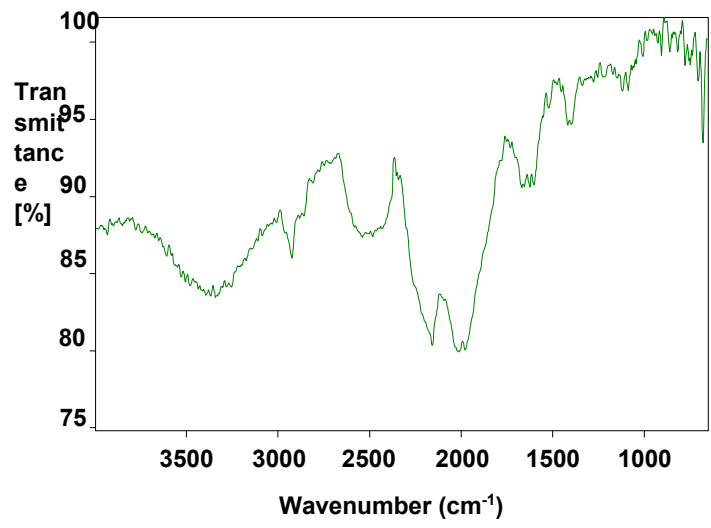

(e)

Figure 4. FT-IR spectra of (a). NMPY), (b) NNDEA, and (c-e) PNMPY-TRX100/NNDEA/OL 37 electrodeposition over OL 37 electrode at galvanostatic method (c) $3 \mathrm{~mA} / \mathrm{cm}^{2}$, (d) $5 \mathrm{~mA} / \mathrm{cm}^{2}$, (e) $8 \mathrm{~mA} / \mathrm{cm}^{2}$ in 5:1 molar ratio for MPY-TRX100: NNDEA and permitted for $20 \mathrm{~min}$.

The meaningful peaks of the spectrum for NNDEA (monomer) and NMPY (monomer) are displayed in Figure 4a,b: the spectrum of MPY can be observed in Figure 4a, where the main specific features of bands towards the aromatic ring in NMPY are evident at 1562 and $1448 \mathrm{~cm}^{-1}$ for $\mathrm{C}=\mathrm{C}$ stretching. The summit at $1214 \mathrm{~cm}^{-1}$ is attributed to the C-N stretching vibration of the pyrrole ring. The distinctive bands at 1368 and $1304 \mathrm{~cm}^{-1}$ are assigned to the N-H stretching vibration of the pyrrole ring. The peak located to 1671 and $1622 \mathrm{~cm}^{-1}$ is related to the $\mathrm{C}=\mathrm{C}$ stretching. The bands which can be determined as "in plane and out of plane" of the CH chains at 1140,1071, and $613 \mathrm{~cm}^{-1}$ are observed in the polymer. In the spectrum of NNDEA from Figure $4 b$, the relationship is ascribed to the stretching vibration of the quinoid and benzenoid ring and may be noticed at 1594 
and $1435 \mathrm{~cm}^{-1}$. The band at nearly $1152 \mathrm{~cm}^{-1}$ is ascribed to $\mathrm{C}-\mathrm{N}$ stretching vibration in aromatic amines. The band placed at $1265 \mathrm{~cm}^{-1}$ is believed to be due to the $\mathrm{C}-\mathrm{H}$ stretching of $\mathrm{CH}_{3},-\mathrm{CH}_{2}$. The peaks presented at 1152, 1071, 1009, and $788 \mathrm{~cm}^{-1}$ are ascribed to the "in plane and out plane" C-H of the aromatic rings. The transmittance spectra of MPY-TRX100/NNDEA/OL37 electrodeposition at various currents applied in a 5:1 molar ratio are depicted in Figure 4c-e [18-23,27]. The significant features peaks at the aromatic ring in PNMPY is seen at 1526 and $1464 \mathrm{~cm}^{-1}$ for $\mathrm{C}=\mathrm{C}$ stretching. The existence bands located at 1560,1548,1471, and $1468 \mathrm{~cm}^{-1}$ are displayed in the stretching vibration of quinoid and benzoid rings (Figure 4c-e). The summit at about $1206 \mathrm{~cm}^{-1}$ represents the C-N of the pyrrole ring. The peaks located at $1378,1309 \mathrm{~cm}^{-1}$ are assigned to the $\mathrm{N}-\mathrm{H}$ stretching vibration of the methylpyrrole ring; the bands indicated at $1651,1621 \mathrm{~cm}^{-1}$ are associated with the $C=C$ stretching. A wide band at $3550 \mathrm{~cm}^{-1}$ and $3300 \mathrm{~cm}^{-1}$ is a result of $\mathrm{N}-\mathrm{H}$ "stretching vibration" related to the attendance of the $\mathrm{N}-\mathrm{H}$ component in N,Ndiethylaniline units; the peaks appearing at 1338 and $1304 \mathrm{~cm}^{-1}$ represent C-N "stretching vibration" in the aromatic amine [13,15,19-23,26,30-34]. The band at 1454 and $1340 \mathrm{~cm}^{-1}$ is associated with the "stretching vibration" of the $\mathrm{CH}_{2}$ and $\mathrm{CH}_{3}$ components in the Triton X100 surfactant. $\mathrm{CH}$ is evidenced through the appearance of the $\mathrm{C}=\mathrm{O}$ bonds, which stretch the modes at $1680 \mathrm{~cm}^{-1}$ and $1260 \mathrm{~cm}^{-1}$, and are most likely connected by the sheltering of the surfactant in the polymer matrix. The small peaks at 1100,1020,960, and $840 \mathrm{~cm}^{-1}$ are associated with the C-O-C vibration in $\left(\mathrm{CH}_{2} \mathrm{CH}_{2} \mathrm{O}\right) \mathrm{n}$ of the surfactant as a dopant on the composite film (Figure 4c-e). The bands that can be seen at 1150, 856, and 781, $1008 \mathrm{~cm}^{-1}$ are attributed to the "in-plane" and "out-plane" C-H of the aromatic rings and to "out of plane" vibration of C-H doped of MPPY in oxalic acid medium (Figure 4c-e) [24-29]. The summit distinguished to "in plane" and "out of plane" of the N-H chains at 1034, 1152, and $640 \mathrm{~cm}^{-1}$ is supposed to be suitable in NMPY-TRX100/NNDEA/OL 37 composite film. By comparing Figure $4 \mathrm{a}, \mathrm{b}$ with Figure $4 \mathrm{c}-\mathrm{e}$, it can be assumed that the PNMPYTRX100/NNDEA composite polymer is electrodeposited on the carbon steel surface. The bands existing on the monomer spectrum (MPY and NNDEA) are present at the spectrum of the composite coated over the carbon steel OL 37 surface.

\subsection{Electrochemical Studies}

\subsubsection{Potentiodynamic Polarization Method}

The electrochemical research has been realized in $0.5 \mathrm{M} \mathrm{H}_{2} \mathrm{SO}_{4}$ solution to evaluate the protection result of the composite coatings versus corrosion. As well, polarization behavior of OL 37 electrode has been studied with MPY-TRX100/NNDEA composite coated carbon steel accomplished by galvanostatic method at varied current densities in different amounts and various deposition periods. The anticorrosion performance of the acquired PNMPY-TRX100/NNDEA/OL37 composite polymer was analyzed in $0.5 \mathrm{M}$ $\mathrm{H}_{2} \mathrm{SO}_{4}$ by potentiodynamic polarization measurements and electrochemical impedance spectroscopy. In this paper, one of the best practices for anticorrosion protection of carbon steel in corrosive environment is the application of the polymeric composite coatings, which examine the corrosion of anodic or cathodic reaction, or both. Polarization curves of uncoated and PNMPY-TRX100/NNDEA-coated OL 37 in $0.5 \mathrm{M} \mathrm{H}_{2} \mathrm{SO}_{4}$ solution are presented in Figures 5-8.

Composite polymer coated surfaces exhibited considerable diminution in anodic and cathodic currents which denoted reduction of the cathodic and anodic reactions. It can be remarked from Figures 5-7 that both the anodic metal dissolving and cathodic hydrogen reduction mechanisms were hindered through the electrodeposition of these organic coatings in the corrosive solution. This fact divulged that the composite coating had an important effect on cathodic and anodic mechanisms of the electrochemical process. Corrosion potential $\left(\mathrm{E}_{\mathrm{corr}}\right)$, corrosion current density $\left(\mathrm{i}_{\mathrm{corr}}\right)$, and anodic and cathodic Tafel slopes made by extrapolation of linear parts of the anodic and cathodic Tafel curves of OL 37 substrate coated by composite polymer are showed in Tables 1 and 2 . These polarization curves show that corrosion potential of the coated substrate of OL37 are displaced at 
more positive potential in comparison with those of the uncovered electrode. This event may be due to the attack of corrosive compounds that get into the pores of composite polymers following the constitution of passive layers which impede corrosive of carbon steel OL37 [18-24].

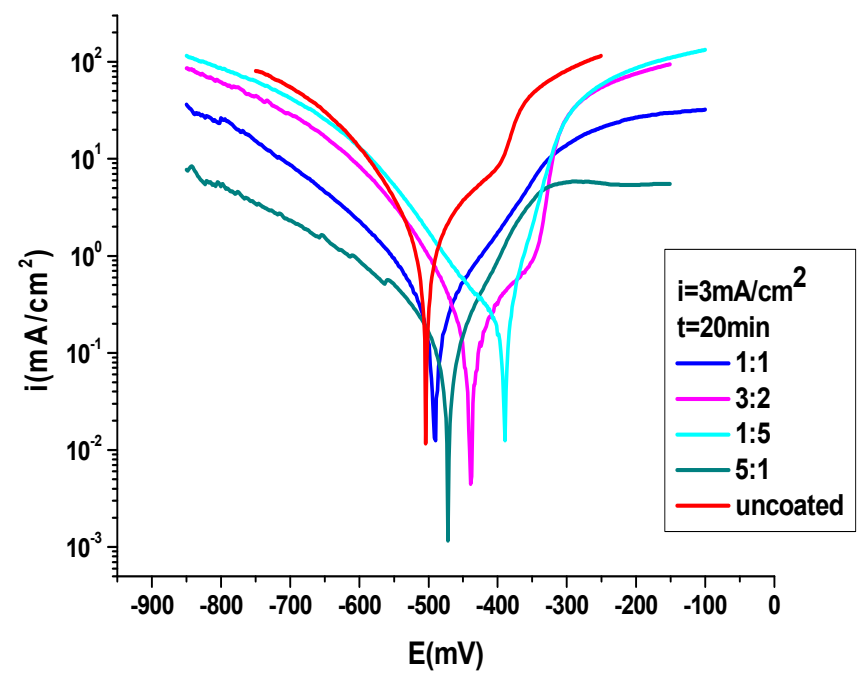

(a)

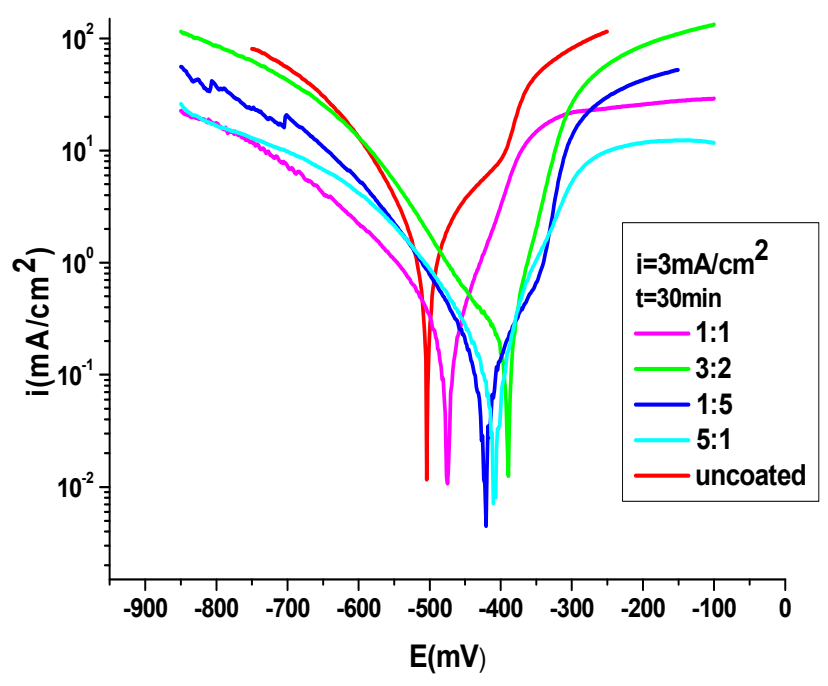

(b)

Figure 5. Polarization curves PNMPY-TRX100/PNNDEA (a) coated and (b) uncoated of OL 37 electrode in $0.5 \mathrm{M} \mathrm{H}_{2} \mathrm{SO}_{4}$ by electrodeposition at $3 \mathrm{~mA} / \mathrm{cm}^{2}$ current density in different molar ratios where the deposition was admitted for 20 and 30 min.

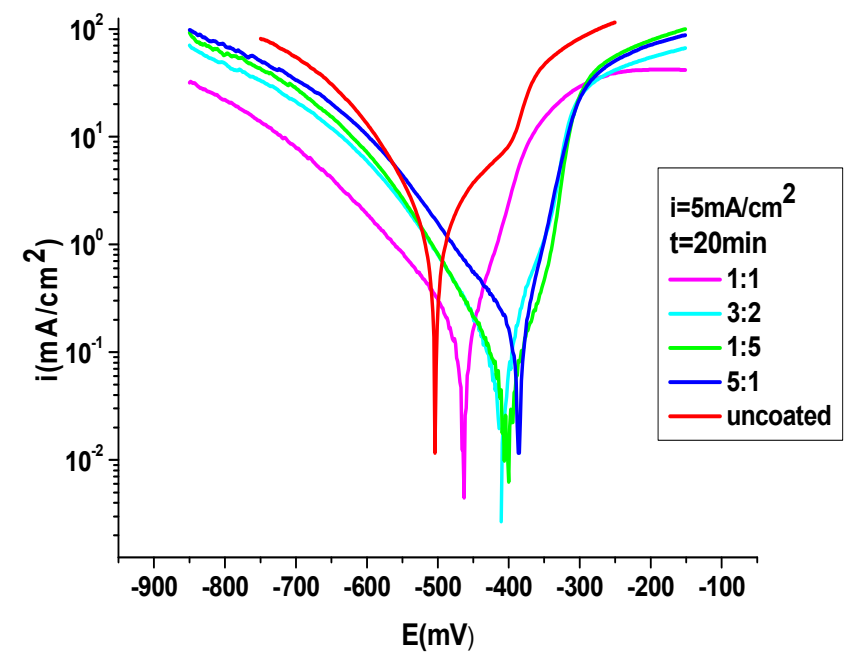

(a)

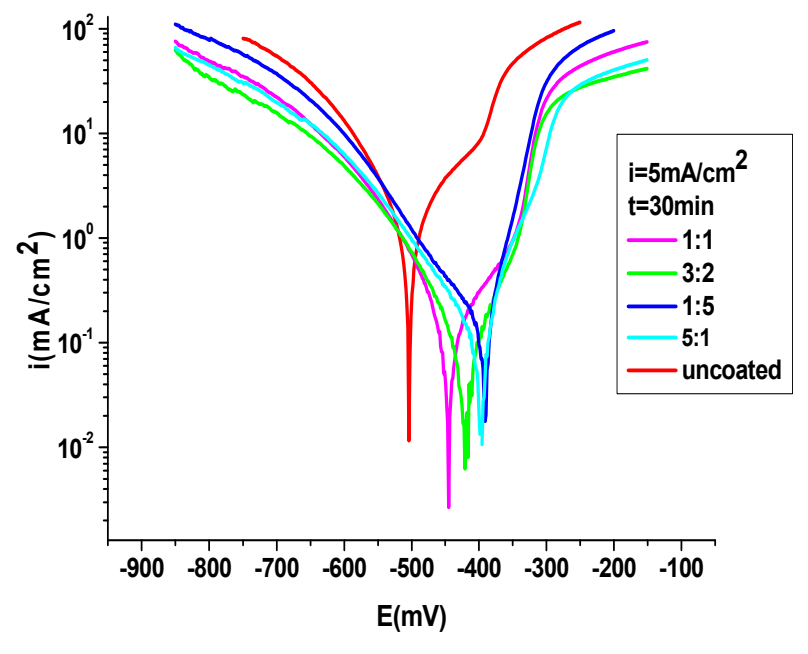

(b)

Figure 6. Polarization curves of PNMPY-TRX100/PNNDEA (a) coated and (b) uncoated of OL 37 in $0.5 \mathrm{M} \mathrm{H}_{2} \mathrm{SO}_{4}$ by electrodeposition at $5 \mathrm{~mA} / \mathrm{cm}^{2}$ current density in different molar ratios where the deposition was permitted for 20 and $30 \mathrm{~min}$. 


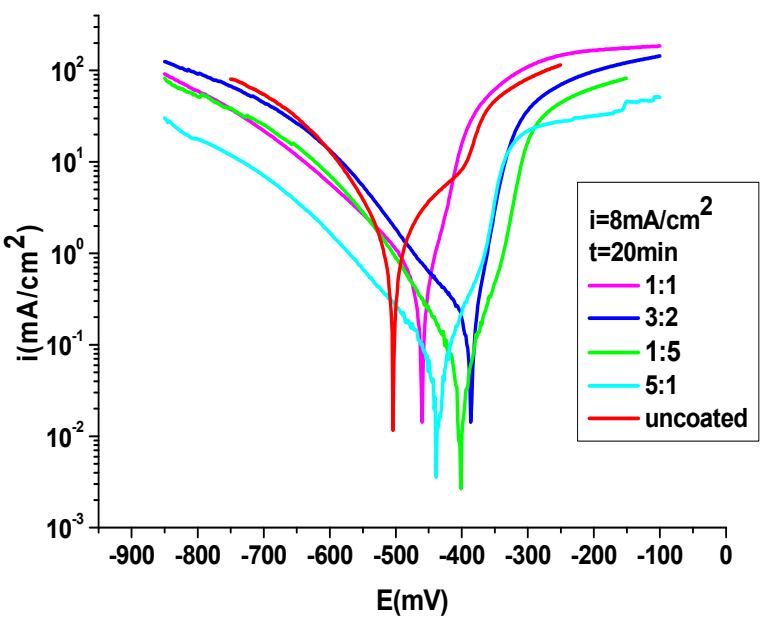

(a)

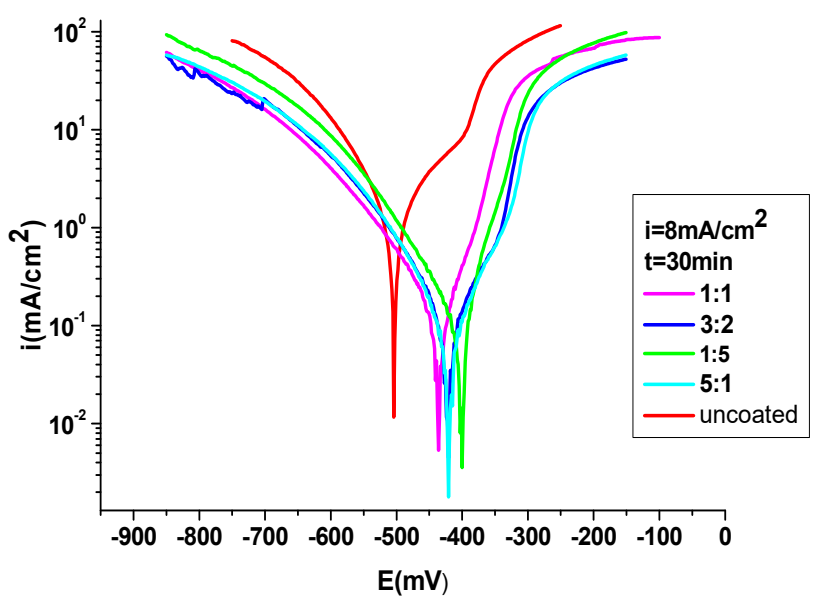

(b)

Figure 7. Polarization curves PNMPY-TRX100/PNNDEA (a) coated and (b) uncoated of OL 37 in $0.5 \mathrm{M} \mathrm{H}_{2} \mathrm{SO}_{4}$ by electrodeposition at $8 \mathrm{~mA} / \mathrm{cm}^{2}$ current density at various molar ratios where the deposition was allowed for 20 and 30 min.

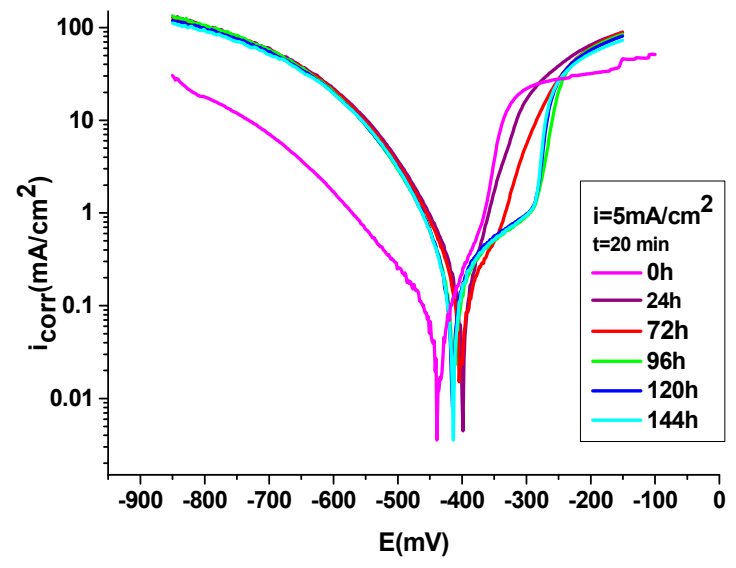

(a)

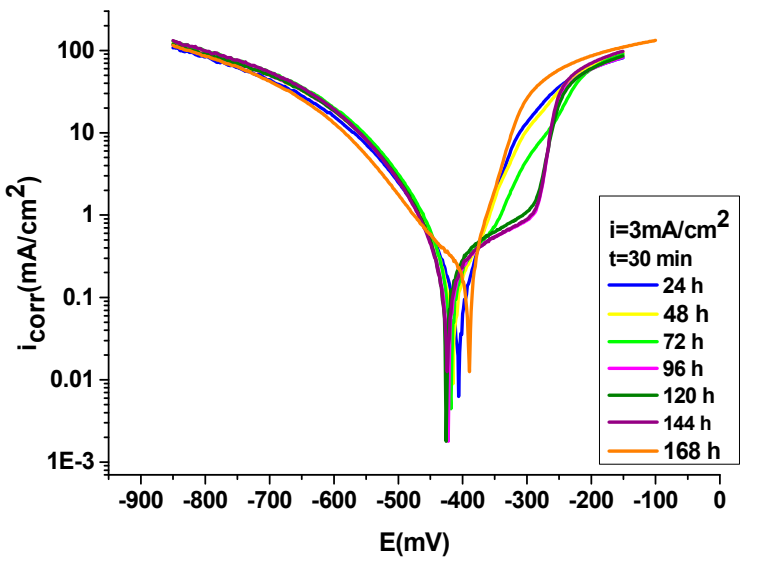

(b)

Figure 8. Polarization curves MPY-TRX100/NNDEA-coated and -uncoated OL 37 electrode in $0.5 \mathrm{M} \mathrm{H}_{2} \mathrm{SO}_{4}$ by electrodeposition at $5 \mathrm{~mA} / \mathrm{cm}^{2}(\mathbf{a})$ and $3 \mathrm{~mA} / \mathrm{cm}^{2}(\mathbf{b})$ in different molar ratios where the deposition was allowed for 20 and $30 \mathrm{~min}$ at different immersion times.

Electrochemical characteristics achieved by extrapolation of the linear zone of the cathodic and anodic Tafel branch of OL 37 electrode uncovered and coated with the composite at various current densities, in different molar ratios, and varied immersion periods are indicated in Tables $1-4$.

The polarization curves in Figures 5-7 and Tables 1-3 show that the electrochemical polarization features of the uncovered surface of OL37 compared to the characteristics of coated OL 37 by electrodeposition at $3 \mathrm{~mA} / \mathrm{cm}^{2}, 5 \mathrm{~mA} / \mathrm{cm}^{2}$, and $8 \mathrm{~mA} / \mathrm{cm}^{2}$ current density at $20 \mathrm{~min}$ and $30 \mathrm{~min}$ for 5:1, 3:2, 1:5, and 1:1 molar ratios of PNMPY-TRX-100/PNNDEA were lower than those for the OL 37 electrode in the $0.5 \mathrm{M} \mathrm{H}_{2} \mathrm{SO}_{4}$ solution, and an excellent anticorrosion effect was shown at $5 \mathrm{~mA} / \mathrm{cm}^{2}$ and $8 \mathrm{~mA} / \mathrm{cm}^{2}$ current density for $5: 1,3: 2$, and 1:5 molar ratios of PNMPY-TRX-100/PNNDEA. The molar ratio of the coating has a higher protective performance because the polymer PNMPY film was doped with a surfactant of Triton X100. The surfactant TRT-X100 as a dopant ion utilized through electropolymerization (introduced in $\mathrm{N}$-methylpyrrole) may have an appreciable action by the ion to modify 
the selectivity assurance of the conductivity polymer. The hydrocarbonate chains of the surfactant adsorb on the metal electrode area hindering the active centers, and, accordingly, the $\mathrm{SO}_{4}{ }^{2-}$ aggressive ion is impeded in affecting the metal area and corrosion protection is accomplished [24-28]. The experimental data denote that the corrosion rate of PNMPYTRX-100/PNNDEA-coated OL37 was manifested to be $\sim 9$ times less than that observed for uncoated OL 37. It was evident that the composite coatings were impeding the attack of the aggressive element $\left(\mathrm{H}_{2} \mathrm{SO}_{4}\right)$ to the electrode area. Polarization behavior of the PNMPYTRX-100/PNNDEA-coated OL 37 electrode revealed that the coated substrate has superior corrosion strength and a lower corrosion rate in comparison to uncoated OL 37.

Table 1. Kinetic Corrosion Parameters of Coated and Uncoated OL37 Electrode in $0.5 \mathrm{M} \mathrm{H}_{2} \mathrm{SO}_{4}$ Solution at $25^{\circ} \mathrm{C}$.

\begin{tabular}{|c|c|c|c|c|c|c|c|c|c|c|}
\hline $\begin{array}{l}\text { The System } \\
\text { PNMPY-TRX100/PNNDEA/OL } 37\end{array}$ & $\begin{array}{l}E_{\text {corr }} \\
(\mathrm{mV})\end{array}$ & $\begin{array}{c}\mathrm{i}_{\text {corr }} \\
\left(\mathrm{mA} / \mathrm{cm}^{2}\right)\end{array}$ & $\begin{array}{c}R_{p} \\
(\Omega \mathrm{cm})\end{array}$ & $\mathbf{R}_{\mathrm{mpy}}$ & $\mathbf{P}_{\mathrm{mm} / \text { year }}$ & $\underset{\left(g / m^{2} h\right)}{K g}$ & $\begin{array}{c}b_{a} \\
(m V / \\
\text { Decade) }\end{array}$ & $\begin{array}{c}-\mathbf{b}_{\mathrm{c}} \\
(\mathrm{mV} / \\
\text { Decade) }\end{array}$ & E (\%) & $\% \mathbf{P}$ \\
\hline $\mathrm{OL} 37+0.5 \mathrm{M} \mathrm{H}_{2} \mathrm{SO}_{4}$ & -504 & 0.892 & 16 & 387 & 9.81 & 8.79 & 98 & 93 & - & \\
\hline $\begin{array}{c}\text { PNMPY-TRX100/PNNDEA } \\
3 \mathrm{~mA} / \mathrm{cm}^{2} 1: 1 \text { molar ratio, } \mathrm{t}=20 \mathrm{~min}\end{array}$ & -442 & 0.171 & 78 & 74 & 1.88 & 1.68 & 85 & 80 & 81 & 0.04 \\
\hline $\begin{array}{l}\text { PNMPY-TRX100/PNNDEA } \\
3 \mathrm{~mA} / \mathrm{cm}^{2} 3: 2 \text { molar ratio }\end{array}$ & -443 & 0.144 & 106 & 62.4 & 1.58 & 1.41 & 99 & 73 & 84 & 0.03 \\
\hline $\begin{array}{l}\text { PNMPY-TRX100/PNNDEA } \\
3 \mathrm{~mA} / \mathrm{cm}^{2} \text { 5:1 molar ratio }\end{array}$ & -452 & 0.083 & 160 & 35.53 & 0.90 & 0.81 & 68 & 94 & 91 & 0.024 \\
\hline $\begin{array}{l}\text { PNMPY-TRX100/PNNDEA } \\
3 \mathrm{~mA} / \mathrm{cm}^{2} \text { 1:5 molar ratio }\end{array}$ & -393 & 0.170 & 66 & 73.66 & 1.86 & 1.43 & 45 & 113 & 81 & 0.017 \\
\hline $\begin{array}{c}\text { PNMPY-TRX100/PNNDEA } \\
3 \mathrm{~mA} / \mathrm{cm}^{2} 1: 1 \text { molar ratio } \mathrm{t}=30 \mathrm{~min}\end{array}$ & -470 & 0.157 & 72 & 68.03 & 1.72 & 1.54 & 58 & 86 & 82 & 0.085 \\
\hline $\begin{array}{l}\text { PNMPY-TRX100/PNNDEA } \\
3 \mathrm{~mA} / \mathrm{cm}^{2} 3: 2 \text { molar ratio }\end{array}$ & -400 & 0.092 & 144 & 40.3 & 1.02 & 0.91 & 47 & 99 & 90 & 0.006 \\
\hline $\begin{array}{l}\text { PNMPY-TRX100/PNNDEA } \\
3 \mathrm{~mA} / \mathrm{cm}^{2} \text { 5:1 molar ratio }\end{array}$ & -409 & 0.086 & 159 & 37.52 & 0.95 & 0.85 & 54 & 84 & 90.5 & 0.007 \\
\hline $\begin{array}{l}\text { PNMPY-TRX100/PNNDEA } \\
3 \mathrm{~mA} / \mathrm{cm}^{2} \text { 1:5 molar ratio }\end{array}$ & -422 & 0.098 & 162 & 42.46 & 1.07 & 0.96 & 80 & 85 & 89 & 0.01 \\
\hline
\end{tabular}

Table 2. Kinetic Corrosion Parameters of Coated and Uncoated OL37 Electrode in $0.5 \mathrm{M} \mathrm{H}_{2} \mathrm{SO}_{4}$ Solution at $25^{\circ} \mathrm{C}$.

\begin{tabular}{|c|c|c|c|c|c|c|c|c|c|c|}
\hline $\begin{array}{l}\text { The System } \\
\text { PNMPY-TRX100/PNNDEA/OL } 37\end{array}$ & $\begin{array}{l}E_{\text {corr }} \\
(m V)\end{array}$ & $\begin{array}{c}\mathrm{i}_{\text {corr }} \\
\left(\mathrm{mA} / \mathrm{cm}^{2}\right)\end{array}$ & $\begin{array}{c}R_{p} \\
(\Omega \mathrm{cm})\end{array}$ & $\mathbf{R}_{\mathrm{mpy}}$ & $\mathbf{P}_{\text {mm/year }}$ & $\underset{\left(g / m^{2} h\right)}{K g}$ & $\begin{array}{c}\mathbf{b}_{\mathbf{a}} \\
(\mathrm{mV} / \\
\text { Decade) }\end{array}$ & $\begin{array}{c}-\mathbf{b}_{\mathrm{c}} \\
(\mathrm{mV} / \\
\text { Decade) }\end{array}$ & E (\%) & $\% \mathbf{P}$ \\
\hline $\mathrm{OL} 37+0.5 \mathrm{M} \mathrm{H}_{2} \mathrm{SO}_{4}$ & -504 & 0.892 & 16 & 387 & 9.81 & 8.79 & 98 & 93 & & \\
\hline $\begin{array}{c}\text { PNMPY-TRX100/PNNDEA } \\
5 \mathrm{~mA} / \mathrm{cm}^{2} 1: 1 \text { molar ratio, } \mathrm{t}=20 \mathrm{~min}\end{array}$ & -458 & 0.101 & 118 & 43.76 & 1.11 & 0.99 & 48 & 89 & 89 & 0.036 \\
\hline $\begin{array}{l}\text { PNMPY-TRX100/PNNDEA } \\
5 \mathrm{~mA} / \mathrm{cm}^{2} \text { 3:2 molar ratio }\end{array}$ & -409 & 0.068 & 192 & 29.46 & 0.74 & 0.66 & 51 & 79 & 92 & 0.007 \\
\hline $\begin{array}{l}\text { PNMPY-TRX100/PNNDEA } \\
5 \mathrm{~mA} / \mathrm{cm}^{2} \text { 5:1 molar ratio }\end{array}$ & -405 & 0.057 & 228 & 24.7 & 0.62 & 0.56 & 50 & 83 & 94 & 0.008 \\
\hline $\begin{array}{l}\text { PNMPY-TRX100/PNNDEA } \\
5 \mathrm{~mA} / \mathrm{cm}^{2} 1: 5 \text { molar ratio }\end{array}$ & -386 & 0.091 & 102 & 39.43 & 1.01 & 0.89 & 40 & 82 & 90 & 0.006 \\
\hline $\begin{array}{c}\text { PNMPY-TRX100/PNNDEA } \\
5 \mathrm{~mA} / \mathrm{cm}^{2} 1: 1 \text { molar ratio } \mathrm{t}=30 \mathrm{~min}\end{array}$ & -446 & 0.107 & 125 & 49.93 & 1.26 & 1.13 & 102 & 70 & 88 & 0.024 \\
\hline $\begin{array}{l}\text { PNMPY-TRX100/PNNDEA } \\
5 \mathrm{~mA} / \mathrm{cm}^{2} \text { 3:2 molar ratio }\end{array}$ & -403 & 0.094 & 123 & 41 & 1.03 & 0.92 & 52 & 99 & 89 & 0.009 \\
\hline $\begin{array}{l}\text { PNMPY-TRX100/PNNDEA } \\
5 \mathrm{~mA} / \mathrm{cm}^{2} \text { 5:1 molar ratio }\end{array}$ & -421 & 0.055 & 199 & 23.83 & 0.60 & 0.54 & 63 & 65 & 94 & 0.008 \\
\hline $\begin{array}{l}\text { PNMPY-TRX100/PNNDEA } \\
5 \mathrm{~mA} / \mathrm{cm}^{2} 1: 5 \text { molar ratio }\end{array}$ & -400 & 0.131 & 96 & 56.7 & 1.44 & 1.28 & 54 & 119 & 85 & 0.011 \\
\hline
\end{tabular}


Table 3. Kinetic Corrosion Parameters of Coated and Uncoated OL37 Electrode in $0.5 \mathrm{M} \mathrm{H}_{2} \mathrm{SO}_{4}$ Solution at $25^{\circ} \mathrm{C}$.

\begin{tabular}{|c|c|c|c|c|c|c|c|c|c|c|}
\hline $\begin{array}{c}\text { The System } \\
\text { PNMPY-TRX100/PNNDEA/OL } 37\end{array}$ & $\begin{array}{l}E_{\text {corr }} \\
(m V)\end{array}$ & $\begin{array}{c}\mathrm{i}_{\text {corr }} \\
\left(\mathrm{mA} / \mathrm{cm}^{2}\right)\end{array}$ & $\underset{(\Omega \mathrm{cm})}{R_{\mathrm{p}}}$ & $\mathbf{R}_{\text {mpy }}$ & $\mathbf{P}_{\text {mm/year }}$ & $\underset{\left(g / m^{2} h\right)}{K g}$ & $\begin{array}{c}\mathbf{b}_{\mathrm{a}} \\
(\mathrm{mV} / \\
\text { Decade })\end{array}$ & $\begin{array}{c}-\mathbf{b}_{\mathrm{c}} \\
(\mathrm{mV} / \\
\text { Decade) }\end{array}$ & $\begin{array}{c}E \\
(\%)\end{array}$ & $\% P$ \\
\hline $\mathrm{OL} 37+0.5 \mathrm{M} \mathrm{H}_{2} \mathrm{SO}_{4}$ & -504 & 0.892 & 16 & 387 & 9.81 & 8.79 & 98 & 93 & - & \\
\hline $\begin{array}{c}\text { PNMPY-TRX100/PNNDEA } \\
8 \mathrm{~mA} / \mathrm{cm}^{2} 1: 1 \text { molar ratio, } \mathrm{t}=20 \mathrm{~min}\end{array}$ & -430 & 0.074 & 116 & 32.06 & 0.81 & 0.72 & 50 & 69 & 92 & 0.018 \\
\hline $\begin{array}{l}\text { PNMPY-TRX100/PNNDEA } \\
3 \mathrm{~mA} / \mathrm{cm}^{2} \text { 3:2 molar ratio }\end{array}$ & -422 & 0.098 & 160 & 42.46 & 1.07 & 0.96 & 81 & 84 & 89 & 0.017 \\
\hline $\begin{array}{l}\text { PNMPY-TRX100/PNNDEA } \\
8 \mathrm{~mA} / \mathrm{cm}^{2} \text { 5:1 molar ratio }\end{array}$ & -423 & 0.057 & 176 & 24.7 & 0.62 & 0.56 & 63 & 65 & 94 & 0.009 \\
\hline $\begin{array}{l}\text { PNMPY-TRX100/PNNDEA } \\
8 \mathrm{~mA} / \mathrm{cm}^{2} 1: 5 \text { molar ratio }\end{array}$ & -401 & 0.092 & 143 & 39.43 & 1.01 & 0.89 & 114 & 86 & 90 & 0.007 \\
\hline $\begin{array}{c}\text { PNMPY-TRX100/PNNDEA } \\
8 \mathrm{~mA} / \mathrm{cm}^{2} 1: 1 \text { molar ratio } \mathrm{t}=30 \mathrm{~min}\end{array}$ & -416 & 0.071 & 179 & 30.6 & 0.78 & 0.39 & 70 & 79 & 92 & 0.008 \\
\hline $\begin{array}{l}\text { PNMPY-TRX100/PNNDEA } \\
8 \mathrm{~mA} / \mathrm{cm}^{2} 3: 2 \text { molar ratio }\end{array}$ & -412 & 0.102 & 107 & 44.2 & 1.12 & 1.04 & 72 & 41 & 89 & 0.0094 \\
\hline $\begin{array}{l}\text { PNMPY-TRX100/PNNDEA } \\
8 \mathrm{~mA} / \mathrm{cm}^{2} \text { 5:1 molar ratio }\end{array}$ & -405 & 0.052 & 221 & 22.53 & 0.56 & 0.51 & 57 & 92 & 94 & 0.0059 \\
\hline $\begin{array}{l}\text { PNMPY-TRX100/PNNDEA } \\
8 \mathrm{~mA} / \mathrm{cm}^{2} 1: 5 \text { molar ratio }\end{array}$ & -404 & 0.067 & 218 & 29.03 & 0.73 & 0.63 & 59 & 88 & 92.5 & 0.0058 \\
\hline
\end{tabular}

Table 4. Kinetic Corrosion Parameters of Coated and Uncoated OL37 Electrode at Various Immersion Periods in $0.5 \mathrm{M}$ $\mathrm{H}_{2} \mathrm{SO}_{4}$ Solutions at $25^{\circ} \mathrm{C}$.

\begin{tabular}{|c|c|c|c|c|c|c|c|c|c|c|}
\hline $\begin{array}{l}\text { The System } \\
\text { PNMPY-TRX100/PNNDEA/OL } 37\end{array}$ & $\begin{array}{l}\text { Immersion } \\
\text { Time (h) }\end{array}$ & $\begin{array}{l}E_{\text {corr }} \\
(\mathrm{mV})\end{array}$ & $\underset{\left(\mathrm{mA} / \mathrm{cm}^{2}\right)}{\mathbf{i}_{\text {corr }}}$ & $\begin{array}{c}R_{\mathrm{p}} \\
(\Omega \mathrm{cm})\end{array}$ & $\mathbf{R}_{\mathrm{mpy}}$ & $\mathbf{P}_{\mathrm{mm} / \text { year }}$ & $\underset{\left(g / m^{2} h\right)}{K g}$ & $\begin{array}{c}\mathrm{b}_{\mathrm{a}} \\
(\mathrm{mV} / \\
\text { Decade })\end{array}$ & $\begin{array}{c}-b_{\mathrm{c}} \\
(\mathrm{mV} / \\
\text { Decade) }\end{array}$ & E (\%) \\
\hline $\mathrm{OL} 37+0.5 \mathrm{M} \mathrm{H}_{2} \mathrm{SO}_{4}$ & & -504 & 0.892 & 16 & 387 & 9.81 & 8.79 & 98 & 93 & \\
\hline $\begin{array}{c}\text { PNMPY-TRX100/PNNDEA } 3 \mathrm{~mA} / \mathrm{cm}^{2} \\
\text { 3:2 molar ratio } \mathrm{t}=30 \mathrm{~min}\end{array}$ & 0 & -400 & 0.092 & 144 & 39.86 & 1.01 & 0.90 & 47 & 99 & 90 \\
\hline $\begin{array}{c}\text { PNMPY-TRX100/PNNDEA } 3 \mathrm{~mA} / \mathrm{cm}^{2} \\
\text { 3:2 molar ratio } \mathrm{t}=30 \mathrm{~min}\end{array}$ & 24 & -409 & 0.093 & 100 & 40.3 & 1.02 & 0.91 & 41 & 47 & 93 \\
\hline $\begin{array}{c}\text { PNMPY-TRX100/PNNDEA } 3 \mathrm{~mA} / \mathrm{cm}^{2} \\
\text { 3:2 molar ratio } \mathrm{t}=30 \mathrm{~min}\end{array}$ & 48 & -418 & 0.095 & 85 & 41.47 & 1.05 & 0.94 & 59 & 50 & 89 \\
\hline $\begin{array}{c}\text { PNMPY-TRX100/PNNDEA } 3 \mathrm{~mA} / \mathrm{cm}^{2} \\
\text { 3:2 molar ratio } \mathrm{t}=30 \mathrm{~min}\end{array}$ & 72 & -422 & 0.107 & 77 & 43.36 & 1.17 & 0.98 & 96 & 66 & 88 \\
\hline $\begin{array}{c}\text { PNMPY-TRX100/PNNDEA } 3 \mathrm{~mA} / \mathrm{cm}^{2} \\
\text { 3:2 molar ratio } \mathrm{t}=30 \mathrm{~min}\end{array}$ & 96 & -428 & 0.129 & 75 & 55.9 & 1.41 & 1.27 & 101 & 67 & 85.5 \\
\hline $\begin{array}{c}\text { PNMPY-TRX100/PNNDEA } 3 \mathrm{~mA} / \mathrm{cm}^{2} \\
\text { 3:2 molar ratio } \mathrm{t}=30 \mathrm{~min}\end{array}$ & 120 & -426 & 0.131 & 81 & 56.76 & 1.44 & 1.29 & 99 & 71 & 85 \\
\hline $\begin{array}{l}\text { PNMPY-TRX100/PNNDEA } 5 \mathrm{~mA} / \mathrm{cm}^{2} \\
5: 1 \text { molar ratio, } \mathrm{t}=20 \mathrm{~min}\end{array}$ & 0 & -386 & 0.091 & 102 & 39.43 & 1.01 & 0.89 & 44 & 47 & 90 \\
\hline $\begin{array}{c}\text { PNMPY-TRX100/PNNDEA } 5 \mathrm{~mA} / \mathrm{cm}^{2} \\
5: 1 \text { molar ratio, } \mathrm{t}=20 \mathrm{~min}\end{array}$ & 24 & -400 & 0.0827 & 96 & 35.83 & 0.909 & 0.814 & 46 & 82 & 91 \\
\hline $\begin{array}{c}\text { PNMPY-TRX100/PNNDEA } 5 \mathrm{~mA} / \mathrm{cm}^{2} \\
5: 1 \text { molar ratio, } \mathrm{t}=20 \mathrm{~min}\end{array}$ & 96 & -404 & 0.103 & 102 & 44.63 & 1.13 & 1.014 & 74 & 57 & 88.5 \\
\hline $\begin{array}{c}\text { PNMPY-TRX100/PNNDEA } 5 \mathrm{~mA} / \mathrm{cm}^{2} \\
5: 1 \text { molar ratio, } \mathrm{t}=20 \mathrm{~min}\end{array}$ & 120 & -413 & 0.172 & 93 & 74.53 & 1.89 & 1.69 & 99 & 68 & 81 \\
\hline $\begin{array}{l}\text { PNMPY-TRX100/PNNDEA } 5 \mathrm{~mA} / \mathrm{cm}^{2} \\
5: 1 \text { molar ratio, } \mathrm{t}=20 \mathrm{~min}\end{array}$ & 144 & -416 & 0.193 & 85 & 83.63 & 2.12 & 1.90 & 101 & 67 & 78.5 \\
\hline $\begin{array}{c}\text { PNMPY-TRX100/PNNDEA } 5 \mathrm{~mA} / \mathrm{cm}^{2} \\
5: 1 \text { molar ratio, } \mathrm{t}=20 \mathrm{~min}\end{array}$ & 168 & -415 & 0.184 & 87 & 79.73 & 2.02 & 1.81 & 104 & 66 & 79 \\
\hline
\end{tabular}

The effect of increasing the immersion time from $0-168 \mathrm{~h}$ on corrosion protection of MPPY-TRX-100/PNNDEA coatings in the corrosion of OL 37 in $0.5 \mathrm{M} \mathrm{H}_{2} \mathrm{SO}_{4}$ was considered by potentiodynamic polarization. The outcome of protection effectiveness of these coatings by immersion times is displayed in Figure 8 and Table 4 . The protection efficiency slowly decreases with the increase in time. Subsequent to the immersion time 
from $96 \mathrm{~h}$, a slight increase in corrosion rate is observed. This is because of the degradation of surface morphology by the increase in the immersion period owing to a modification of the active surface, which may be due to some imperfections existing on the protective film permitting the admittance of aggressive ions at the metal/composite interface. It is evident that after the $96 \mathrm{~h}$ immersion period, the coating efficacy is $80 \%$, which indicates that the composite has a lengthy period as an effective protector for OL 37 in $0.5 \mathrm{M} \mathrm{H}_{2} \mathrm{SO}_{4}$ medium.

Figures 5-7 show that the lowest corrosion current density and the greatest corrosion protection were acquired with PNMPY-TRX-100/PNNDEA composite coated below $5 \mathrm{~mA} / \mathrm{cm}^{2}$ and $8 \mathrm{~mA} / \mathrm{cm}^{2}$ applied current density (at 5:1, 3:2 molar ratio), and very good protection was attained at $3 \mathrm{~mA} / \mathrm{cm}^{2}$ current density (at 5:1 molar ratio) compared to the electrode not covered in the corrosive medium of $0.5 \mathrm{M} \mathrm{H}_{2} \mathrm{SO}_{4}$. The corrosion process of OL 37 coated with composite polymer PNMPY-TRX-100/PNNDEA and uncoated in $\mathrm{H}_{2} \mathrm{SO}_{4}$ solution could be the cause of this [19,27-29]:

Anodic process:

Dissolution of Metal $(\mathrm{M}=\mathrm{Fe})$ as anodic process

$$
\begin{aligned}
\mathrm{M} & \rightarrow \mathrm{M}^{\mathrm{n}+}+\mathrm{ne}^{-} \\
\mathrm{PMPY}_{\text {undoped }}-\mathrm{ne}^{-} & \rightarrow \mathrm{PMPY}_{\text {doped }} \\
\text { PNNDEA }_{\text {undoped }}-\mathrm{ne}^{-} & \rightarrow \text { PNNDEA }_{\text {doped }}
\end{aligned}
$$

Cathodic process:

The oxygen reduction as cathodic reaction

$$
\begin{gathered}
\frac{1}{2} \mathrm{O}_{2}+\mathrm{H}_{2} \mathrm{O}+2 \mathrm{e} \rightarrow 2 \mathrm{HO}^{-} \\
\text {PMPY }_{\text {doped }}+\text { nePMPY } \\
\text { PNNDEped }_{\text {doped }}+\mathrm{ne}^{-} \rightarrow \text { PNNDEA }_{\text {undoped }}
\end{gathered}
$$

Chemical reactions:

$$
\mathrm{M}^{2+}+2 \mathrm{OH}^{-} \rightarrow \mathrm{M}(\mathrm{OH})_{2} \rightarrow \mathrm{M}(\mathrm{OH})_{3} \rightarrow \mathrm{M}_{2} \mathrm{O}_{3}
$$

The porosity of these coatings (PNMPY-TRX100/PNNDEA) is a significant characteristic for considering whether a coating is relevant or not for protection. The porosity of the coatings was evaluated with the subsequent relationship [19,28,33]:

$$
P=\frac{\operatorname{Rp}(\text { uncoated })}{\operatorname{Rp}(\text { coated })} 10^{-\left(\mathrm{I} \Delta E_{\text {corr }} \mathrm{I} / \beta_{a}\right)}
$$

$P$ is total porosity, $\mathrm{Rp}$ is the polarization resistance for uncoated and coated electrodes, $\Delta E_{\text {corr }}$ the difference among corrosion potential, 1 and $\beta_{a}$ is the anodic Tafel slope for the uncoated electrode.

It can be noticed in Tables 1-3 that the porosities of PNMPY-TRX100/PNNDEA-coated OL 37 electrode by galvanostatic deposition method are $0.005,0.006,0.007,0.008$, and 0.0094 (at current densities applied: $5 \mathrm{~mA} / \mathrm{cm}^{2}, 3 \mathrm{~mA} / \mathrm{cm}^{2}$, and $8 \mathrm{~mA} / \mathrm{cm}^{2}$ in 5:1, 3:2, 1:1 molar ratio). The remarkably smaller size of the porosity in the PNMPY-TRX100/NNDEA coatings manifests appreciable improvement of the anticorrosive result by hindering the admission of the corrosive agent onto the OL 37 working electrode surface. The PNMPYTRX100/PNNDEA coatings obtained at $5 \mathrm{~mA} / \mathrm{cm}^{2}$ current density in molar ratios of 5:1 and 3:2 NMPY-TRX100: NNDEA at $20 \mathrm{~min}$ and $30 \mathrm{~min}$ admitted and at $8 \mathrm{~mA} / \mathrm{cm}^{2}$ current density in molar ratios of 5:1 and 1:1 NMPY-TRX100: NNDEA at 30 min permitted polymer exhibited higher corrosion protection efficiencies than $3 \mathrm{~mA} / \mathrm{cm}^{2}$ current density in the same circumstances. 


\subsubsection{Electrochemical Impedance Spectroscopy (EIS)}

The corrosion protection impact of PNMPY-TRX100/PNNDEA-coated OL 37 in $\mathrm{H}_{2} \mathrm{SO}_{4}$ medium was examined by electrochemical impedance spectroscopy (EIS). Impedance tests were realized at open circuit potential at the frequency interval of $100 \mathrm{kHz}$ to $0.04 \mathrm{~Hz}$ with an $\mathrm{AC}$ wave of $\pm 10 \mathrm{mV}$ (peak-to-peak), and the impedance tests were carried out at a rate of 10 points per decade of change in frequency. EIS data was provided regarding examination of the anticorrosive properties of the new composite: a protective film at OL 37 corrosion. Figure $9 \mathrm{a}-\mathrm{f}$ depicts the Nyquist impedance graph registered for PNMPYTRX100/PNNDEA coatings of the OL 37 electrode and for the uncoated electrode in the sulfuric acid solution. It can be noticed from Figure $9 \mathrm{a}-\mathrm{f}$ the Nyquist diagrams for PNMPY-TRX100/PNNDEA coated on a working specimen indicate just one semicircle that is representative of a charge transfer process. Figure $9 \mathrm{a}-\mathrm{f}$ likewise reveals that the diameters of the capacitance loops with the composite coatings are greater than those uncovered, and the magnitudes of these diameters rise with the consolidation of composite coatings, suggesting that these new composite coatings have excellent protection properties on OL37 specimen in $0.5 \mathrm{M} \mathrm{H}_{2} \mathrm{SO}_{4}$ medium. It is clear from the Nyquist plots that the impedance response of OL 37 was significantly improved through the depositing of the coatings which and the attainment of protective film as evidenced in the presence of the PNMPY-TRX100/PNNDEA composite polymer.

In addition, these capacitive loops are not accurate semicircles, and this event is ascribed at frequency dispersion point, mainly attributed to rugosity and inhomogeneities of the metal surface [26-30]. Figure 9 depicts the diameters of the capacitance loops for coatings obtained at $5 \mathrm{~mA} / \mathrm{cm}^{2}$ to $5: 1,3: 2$, and $1: 5$ molar ratios and $8 \mathrm{~mA} / \mathrm{cm}^{2}$ at $5: 1,1: 1$ molar ratio, and $3 \mathrm{~mA} / \mathrm{cm}^{2}$ to 5:1, 3:2 molar ratios (at time 20 and $30 \mathrm{~min}$ ) are higher than those uncovered, assuming a considerable protection affect for OL 37 electrode in corrosive medium. It can be observed from Figure 9 that the diameters of the capacitance loops of PNMPY-TRX100/PNNDEA/OL37 coatings acquired by galvanostatic technique at $5 \mathrm{~mA} / \mathrm{cm}^{2}$ and $3 \mathrm{~mA} / \mathrm{cm}^{2}$ (in molar ratio at 5:1) are bigger than those accomplished at $8 \mathrm{~mA} / \mathrm{cm}^{2}$ applied current density, and as a consequence, the protection effectiveness of this composite is greater.

Bode plots displayed in Figure 10a-f are in concordance with the Nyquist graphs (Figure 9). The Bode diagrams for the PNMPY-TRX100/PNNDEA coating (see Figure 10) revealed that the impedance modulus, at small frequencies, rise with the increase of the consolidation of coatings, showing that the deposition of the protective film of composite polymer improves the corrosion resistance of the elaborate $\mathrm{OL} 37$ in the $\mathrm{H}_{2} \mathrm{SO}_{4}$ medium. It is obvious that uncoated OL 37 electrodes denote one time constant appropriate at a phase angle of $45^{\circ}$ at medium and small frequencies; this exhibits an inductive behavior by reduced diffusive inclination. In Figure 10 it can be distinguished that in the presence of composite coatings on the graph-phase angle versus the frequency logarithm presents a maximum, fixed at a designated phase angle of approximating $70^{\circ}$. In this situation the electrode has a higher capacitive comportment in accordance with the Nyquist diagrams and experimental tests attained by potentiodynamic polarization. An increase in $Z_{\text {mod }}$ results in higher protection ability and it is also clear that $Z_{\text {mod }}$ rises when the coating has consolidated. Therefore, a greater $Z_{\text {mod }}$ determines superior protection efficiency. 


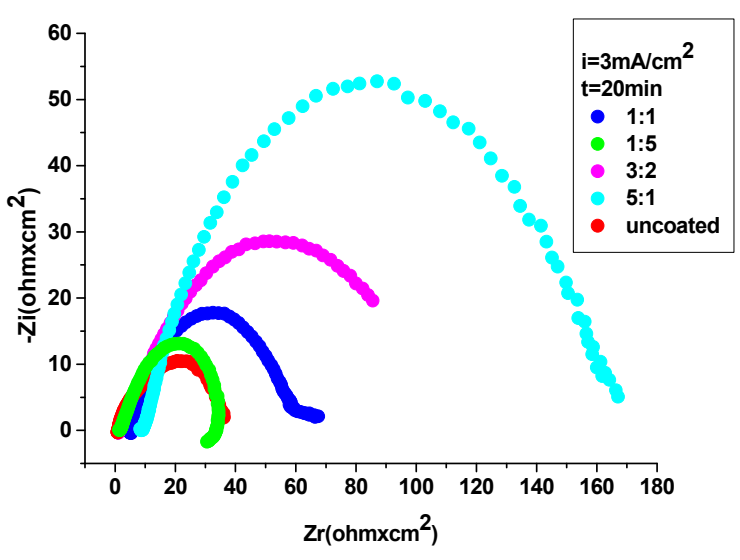

(a)

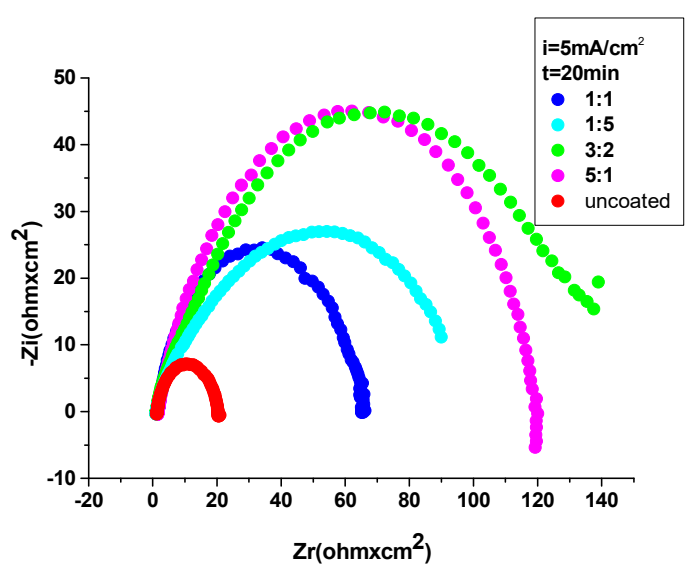

(c)

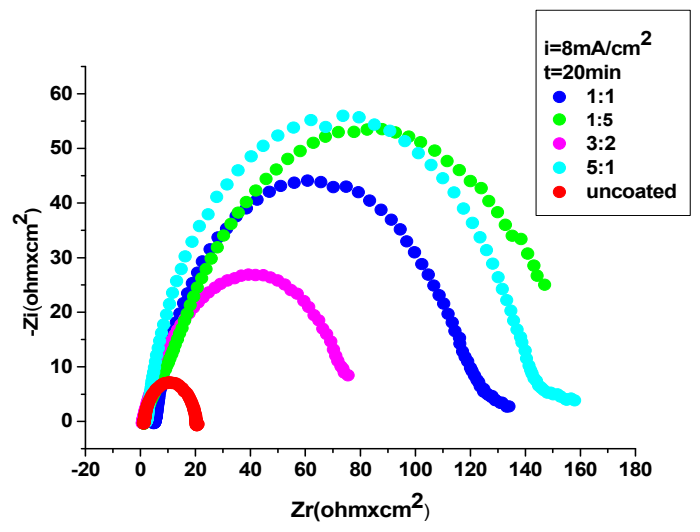

(e)

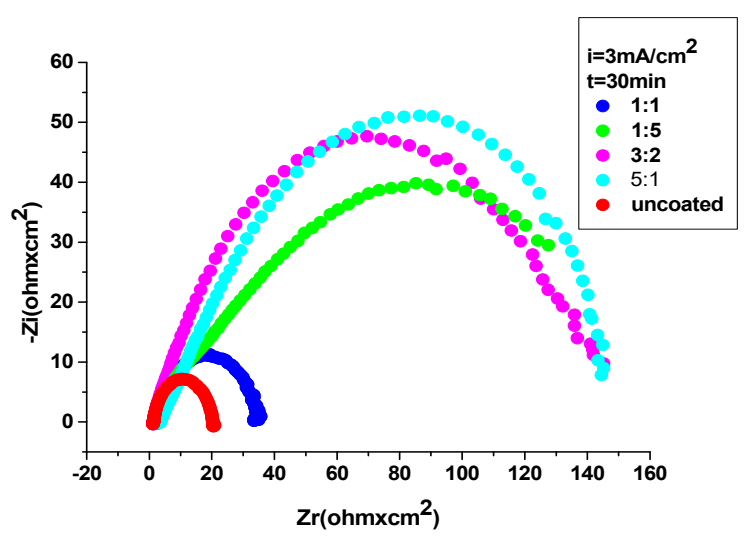

(b)

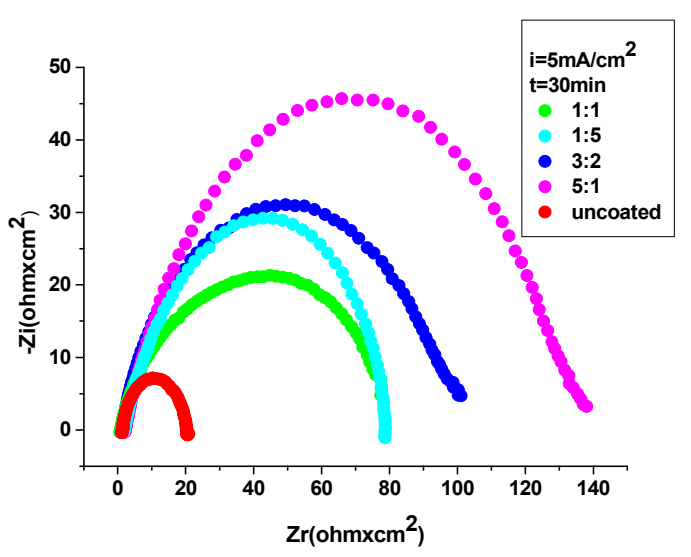

(d)

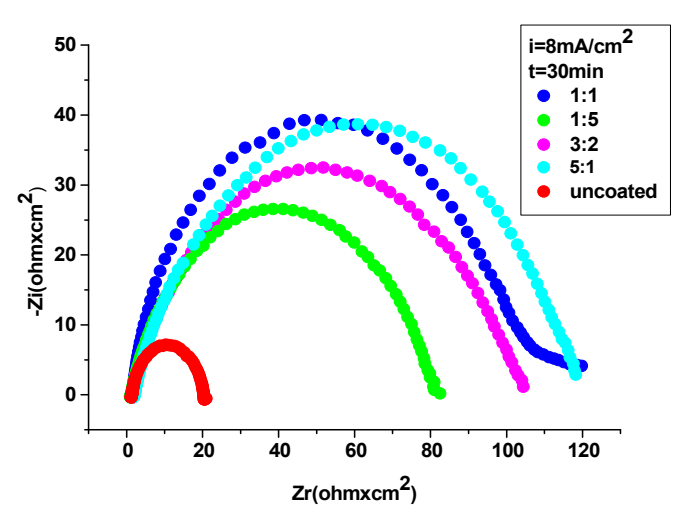

(f)

Figure 9. Nyquist plots for uncoated and PNMPY-TRX100/PNNDEA-coated OL 37 electrode by galvanostatic method at $3 \mathrm{~mA} / \mathrm{cm}^{2}$ for $20 \mathrm{~min}(\mathbf{a})$ and $30 \mathrm{~min} \mathrm{(b)}$, at $5 \mathrm{~mA} / \mathrm{cm}^{2}$ for $20 \mathrm{~min}(\mathbf{c})$ and $30 \mathrm{~min}(\mathbf{d})$, at $8 \mathrm{~mA} / \mathrm{cm}^{2}$ for $20 \mathrm{~min}(\mathbf{e})$ and $30 \mathrm{~min}$ (f) at varied molar ratios for PNMPY-TRX100 and PNNDEA. 


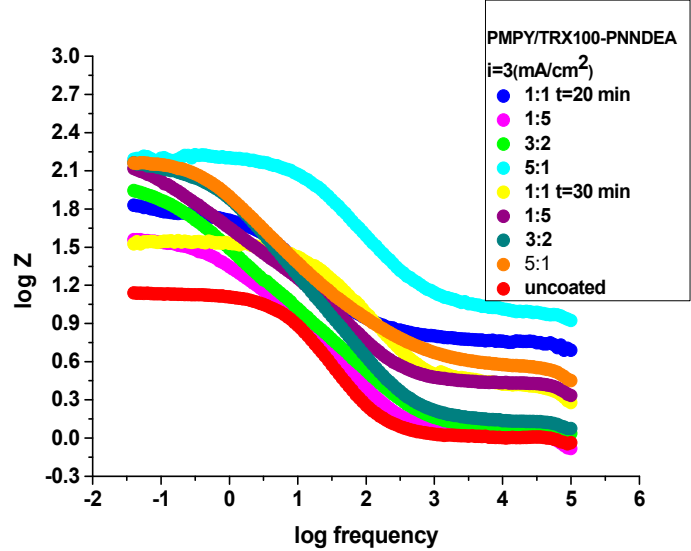

(a)

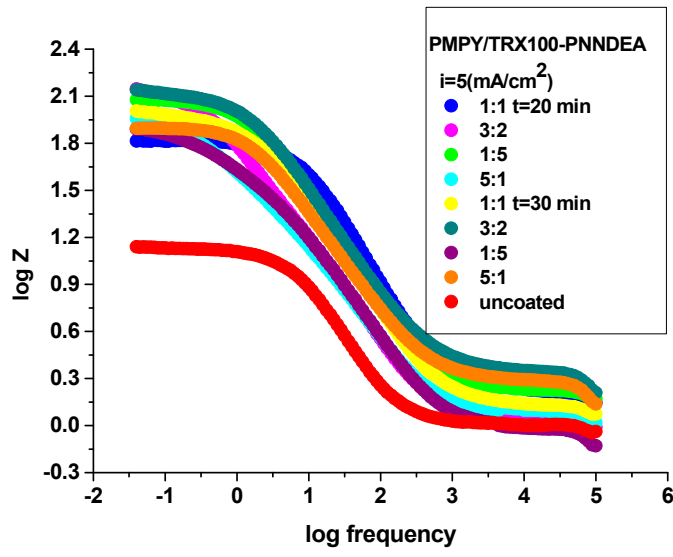

(c)

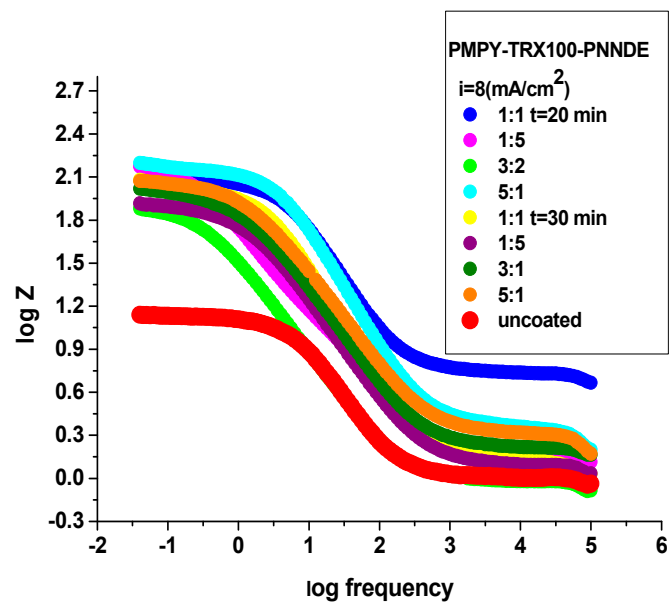

(e)

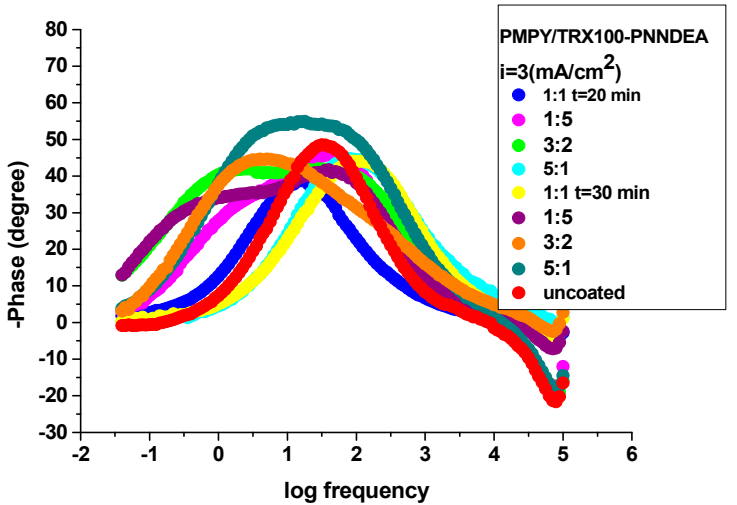

(b)

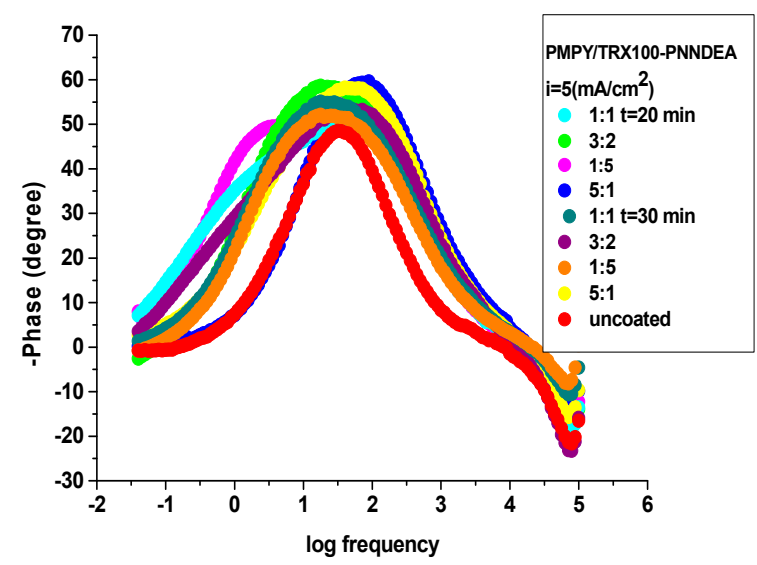

(d)

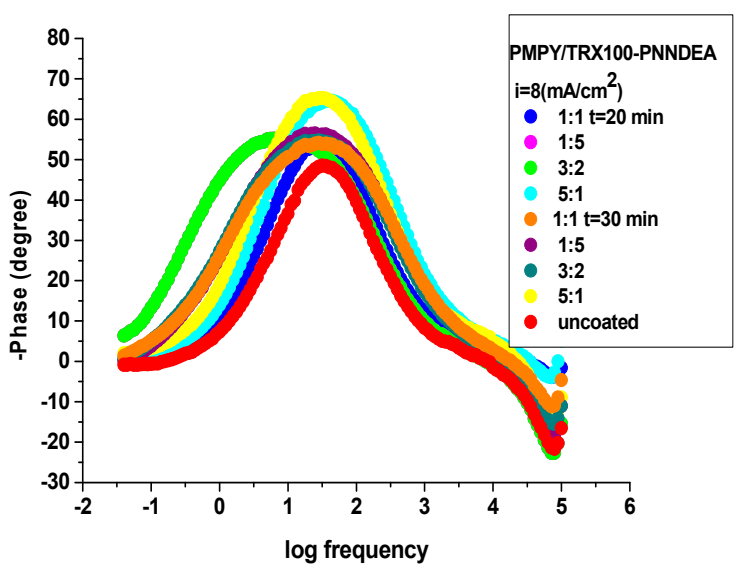

(f)

Figure 10. Bode plots for uncoated and PNMPY-TRX100/PNNDEA-coated of OL 37 electrodes by galvanostatic method at $3 \mathrm{~mA} / \mathrm{cm}^{2}$ for $20 \mathrm{~min}(\mathbf{a})$ and $30 \mathrm{~min} \mathrm{(b)}$, at $5 \mathrm{~mA} / \mathrm{cm}^{2}$ for $20 \mathrm{~min}(\mathbf{c})$ and $30 \mathrm{~min}(\mathbf{d})$, at $8 \mathrm{~mA} / \mathrm{cm}^{2}$ for $20 \mathrm{~min}(\mathbf{e})$ and $30 \mathrm{~min}$ (f) at varied molar ratios for PNMPY-TRX100 and PNNDEA.

The examination of the experimental results was established by fitting the data to the appropriate equivalent circuit indicated in Figure 11, and the varied impedance features like the solution resistance $\left(R_{s}\right)$, the charge transfer resistance $\left(R_{c t}\right)$, the capacitance of the double layer $\left(\mathrm{C}_{\mathrm{dl}}\right)$, and protection performance were taken into account and recorded in Table 5 . In 
addition, in the involved frequency interval an equivalent circuit model was propounded in sequence to fit the acquired EIS tests. In this fact, the constant phase element, $\mathrm{CPE}$, is submitted in the circuit as an alternative for a pure double layer capacitor $\left(C_{\mathrm{dl}}\right)$ to provide a more precise fit. The CPE is utilized to depict the depression of the capacitance semicircle, which is attributed to an area of heterogeneity from area roughness and impurities [23-28]. The impedance of CPE can be explained as: $Z_{\mathrm{CPE}}=\mathrm{Y}_{0}{ }^{-1}(j \omega)^{-n}$, where $\omega$ is the angular frequency, $j$ is the imaginary number $\left(j^{2}=-1\right), Y_{0}$ is the amplitude corresponding to a capacitance, and $\mathrm{n}$ is the phase shift. The evaluation of $\mathrm{n}$ yields particulars regarding the degree of metal area inhomogeneity [26-30]. The bigger the $\mathrm{n}$ amount is, the less area roughness there is, i.e., diminished area inhomogeneity. The CPE can cause resistance when $\left.\mathrm{n}=0, \mathrm{Y}_{0}=\mathrm{R}\right)$, capacitance is $\mathrm{n}=1\left(\mathrm{Y}_{0}=\mathrm{C}\right)$, and inductance when $\mathrm{n}=-1\left(\mathrm{Y}_{0}=1 / \mathrm{L}\right)$, or Warburg impedance as $n=0.5\left(Y_{0}=W\right)$ established on the estimation of $n[27,31-35]$.

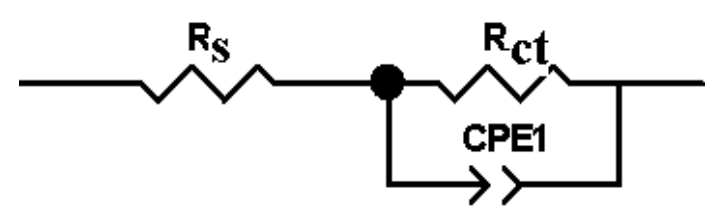

Figure 11. Equivalent circuit.

Table 5. EIS Parameters of PNMPY-TRX100/PNNDEA-Coated and -Uncoated of OL37 Electrode in $0.5 \mathrm{M} \mathrm{H}_{2} \mathrm{SO}_{4} \mathrm{Solutions}$ at $25{ }^{\circ} \mathrm{C}$.

\begin{tabular}{|c|c|c|c|c|}
\hline $\begin{array}{l}\text { The System } \\
\text { PNMPY-TRX100/PNNDEA/OL } 37\end{array}$ & $\mathbf{R}_{\mathrm{S}}\left(\mathrm{ohm} \cdot \mathrm{cm}^{2}\right)$ & $\mathbf{R}_{\mathrm{ct}}\left(\mathrm{ohm} \cdot \mathrm{cm}^{2}\right)$ & $\begin{array}{c}\mathrm{C}_{\mathrm{dl}} \\
\left(\mu \mathrm{Fcm}^{-2}\right)\end{array}$ & $\mathrm{E} \%$ \\
\hline $\mathrm{OL} 37+0.5 \mathrm{M} \mathrm{H}_{2} \mathrm{SO}_{4}$ & 1.032 & 18 & 484 & \\
\hline PNMPY-TRX100/PNNDEA $3 \mathrm{~mA} / \mathrm{cm}^{2} 1: 1$ molar ratio, $\mathrm{t}=20 \mathrm{~min}$ & 3.6 & 65 & 220 & 65 \\
\hline PNMPY-TRX100/PNNDEA $3 \mathrm{~mA} / \mathrm{cm}^{2}$ 3:2 molar ratio & 0.94 & 170 & 84 & 90 \\
\hline PNMPY-TRX100/PNNDEA $3 \mathrm{~mA} / \mathrm{cm}^{2}$ 5:1 molar ratio & 2.44 & 230 & 62 & 93 \\
\hline PNMPY-TRX100/PNNDEA $3 \mathrm{~mA} / \mathrm{cm}^{2}$ 1:5 molar ratio & 1.31 & 130 & 109 & 87 \\
\hline PNMPY-TRX100/PNNDEA $3 \mathrm{~mA} / \mathrm{cm}^{2} 1: 1$ molar ratio $\mathrm{t}=30 \mathrm{~min}$ & 2.45 & 45 & 317 & 68 \\
\hline PNMPY-TRX100/PNNDEA 3 mA $/ \mathrm{cm}^{2}$ 3:2 molar ratio & 2.41 & 161 & 89 & 89 \\
\hline PNMPY-TRX100/PNNDEA $3 \mathrm{~mA} / \mathrm{cm}^{2}$ 5:1 molar ratio & 2.81 & 220 & 65 & 92 \\
\hline PNMPY-TRX100/PNNDEA $3 \mathrm{~mA} / \mathrm{cm}^{2}$ 1:5 molar ratio & 1.33 & 144 & 99 & 88 \\
\hline PNMPY-TRX100/PNNDEA $5 \mathrm{~mA} / \mathrm{cm}^{2} 1: 1$ molar ratio, $\mathrm{t}=20 \mathrm{~min}$ & 1.59 & 66 & 216 & 74 \\
\hline PNMPY-TRX100/PNNDEA $5 \mathrm{~mA} / \mathrm{cm}^{2}$ 3:2 molar ratio & 0.95 & 133 & 107 & 87 \\
\hline PNMPY-TRX100/PNNDEA 5 mA/ $\mathrm{cm}^{2}$ 5:1 molar ratio & 3.03 & 168 & 85 & 90 \\
\hline PNMPY-TRX100/PNNDEA $5 \mathrm{~mA} / \mathrm{cm}^{2}$ 1:5 molar ratio & 1.94 & 123 & 115 & 86 \\
\hline PNMPY-TRX100/PNNDEA $5 \mathrm{~mA} / \mathrm{cm}^{2} 1: 1$ molar ratio $\mathrm{t}=30 \mathrm{~min}$ & 0.97 & 81 & 176 & 80 \\
\hline PNMPY-TRX100/PNNDEA 5 mA/ $\mathrm{cm}^{2}$ 3:2 molar ratio & 0.63 & 111 & 128 & 85 \\
\hline PNMPY-TRX100/PNNDEA $5 \mathrm{~mA} / \mathrm{cm}^{2}$ 5:1 molar ratio & 2.17 & 144 & 99 & 88 \\
\hline PNMPY-TRX100/PNNDEA $5 \mathrm{~mA} / \mathrm{cm}^{2}$ 1:5 molar ratio & 2.23 & 100 & 142 & 83 \\
\hline PNMPY-TRX100/PNNDEA $8 \mathrm{~mA} / \mathrm{cm}^{2} 1: 1$ molar ratio $\mathrm{t}=20 \mathrm{~min}$ & 4.82 & 130 & 109 & 87 \\
\hline PNMPY-TRX100/PNNDEA $8 \mathrm{~mA} / \mathrm{cm}^{2} 3: 2$ molar ratio & 1.08 & 84 & 170 & 80 \\
\hline PNMPY-TRX100/PNNDEA 8 mA/ $\mathrm{cm}^{2}$ 5:1 molar ratio & 2.03 & 179 & 80 & 91 \\
\hline PNMPY-TRX100/PNNDEA $8 \mathrm{~mA} / \mathrm{cm}^{2}$ 1:5 molar ratio & 1.78 & 153 & 93 & 89 \\
\hline PNMPY-TRX100/PNNDEA $8 \mathrm{~mA} / \mathrm{cm}^{2} 1: 1$ molar ratio $\mathrm{t}=30 \mathrm{~min}$ & 0.92 & 117 & 121 & 86 \\
\hline PNMPY-TRX100/PNNDEA $8 \mathrm{~mA} / \mathrm{cm}^{2}$ 3:2 molar ratio & 1.13 & 89 & 160 & 81 \\
\hline PNMPY-TRX100/PNNDEA $8 \mathrm{~mA} / \mathrm{cm}^{2}$ 5:1 molar ratio & 1.41 & 129 & 110 & 87 \\
\hline PNMPY-TRX100/PNNDEA $8 \mathrm{~mA} / \mathrm{cm}^{2}$ 1:5 molar ratio & 1.23 & 113 & 126 & 85 \\
\hline
\end{tabular}


The data achieved by EIS show that the charge transfer resistance $R_{c t}$ was raised and the double layer capacitance $\mathrm{Cdl}$ decreased by composite coatings. As an effect of the rise of $R_{c t}$ at values by the composite coatings the protection efficiency increased significantly which shows that coating exhibits appreciated protection for the corrosion of the OL 37 electrode. The diminution in Cdl can cause a decrease in the local dielectric constant and/or a rise in the thickness of the electrical double layer, signifying the attendance of composite functions by adsorption at the interface of the substrate/medium. The composite electrodeposited over the substrate of OL 37 electrodes represent a protective film on the OL 37 substrate. By increasing in the value of Rct, the performance of protection is also raised. The Nyquist and Bode diagrams insinuate that the process of corrosion was stopped by electrodeposition of PNMPY-TRX100/PNNDEA composite coatings and this situation is realized as a diffusion barrier and through a charge transfer process. Consequently, the protection efficiency can be estimated employing the subsequent equation: IE $(\%)=R_{c t}-R_{0 c t} / R_{c t} \times 100$, where $R_{c t}$ and $R_{0 c t}$ are the charge transfer resistance quantities with and without the composite polymer. The double layer capacitance $\left(\mathrm{C}_{\mathrm{dl}}\right)$ was assessed by the relationship: $\mathrm{Cdl}=1 / 2 \pi \mathrm{f}_{\mathrm{ma}} \times \mathrm{R}_{\mathrm{ct}}$, where $\mathrm{f}_{\max }$ is the frequency at which the imaginary constituent of the impedance is biggest.

\subsection{SEM Analysis}

The morphology structure of the PNMPY-TRX100/PNNDEA composite coatings acquired onto the OL 37 surface was explored by scanning electron microscopy (SEM). The SEM micrographs of PNMPY-TRX100/PNNDEA, coatings electrosynthesized in various situations on OL37 working specimen are described in Figure 12. The SEM images of PNMPY coating obtained on OL 37 substrate depicted in Figure 12a display homogeneous, cauliflower-like morphology shaped by microspherical granules $4 \mu \mathrm{m}$ in size with medium width of $20 \mu \mathrm{m}$ [19-24]. It can be noticed from Figure 12b that the morphology of PNNDEA coating was similar to the globular composition because of the growth aggregates formed like round grains [25-29]. Figure 12c-f illustrates a dense black film of the PNMPY-TRX100/PNNDEA attained by the galvanostatic method showing that the coating composite was accomplished.

It can be seen in Figure 12c-g that the PNMPY-TRX100/PNNDEA composite revealed a uniform shape of cauliflower-like composition by a short globular microstructure ascribed densely onto the carbon steel surface was determined, which corresponds with the literature [26-36]. The grains are $5 \mu \mathrm{m}$ long with a medium thickness of $10 \mu \mathrm{m}$. These micrographs displayed a possible uniform film to coat the OL 37 substrate so that no crevice on the coating is distinguished. The dopant surfactant (TRX-100) incorporated in conducting polymers affects both the electropolymerization mechanism and the characteristics of the acquired composite. After an immersion period of 0 and $168 \mathrm{~h}$ in $0.5 \mathrm{M} \mathrm{H}_{2} \mathrm{SO}_{4}$ solution, obvious modifications of the surface morphology of the coating occurred after the electrochemical test. The diffusion of corrosive ions $\mathrm{SO}_{4}{ }^{2-}$ into the composite coating can be seen from the micrographs on Figure 12h-j. 


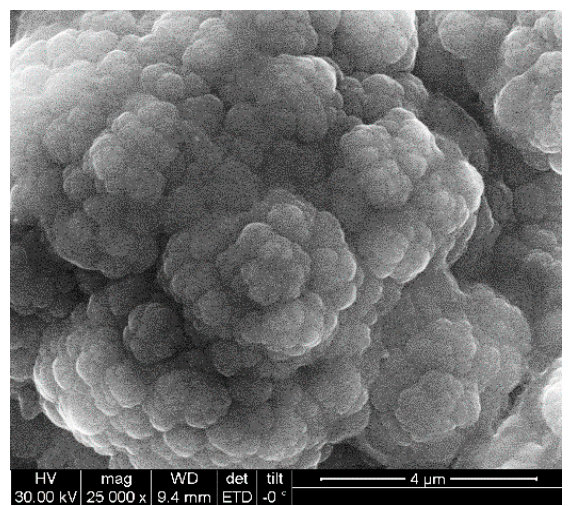

(a)

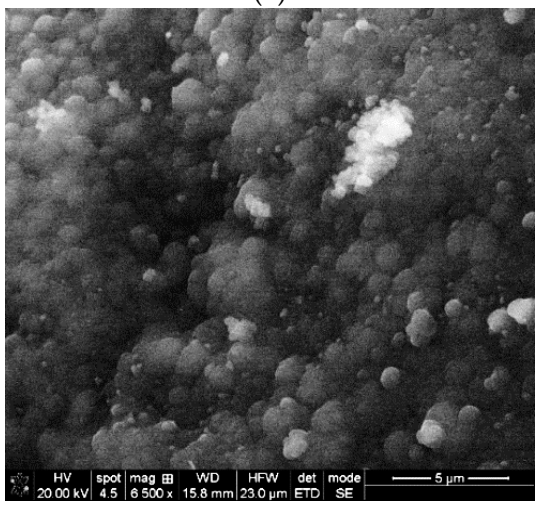

(d)

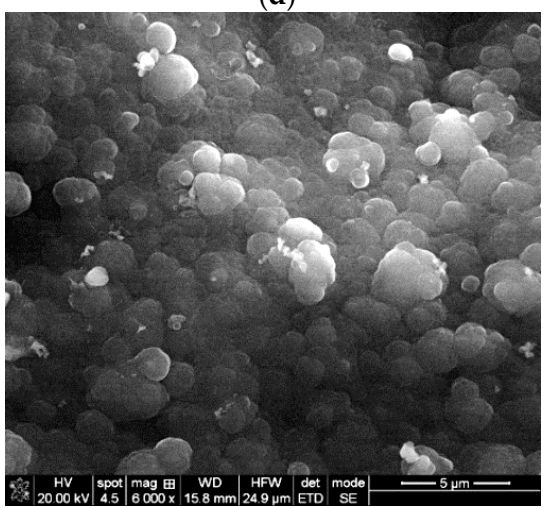

(g)

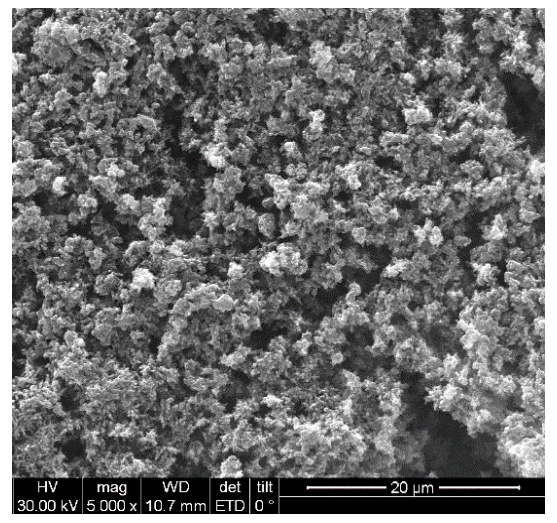

(b)

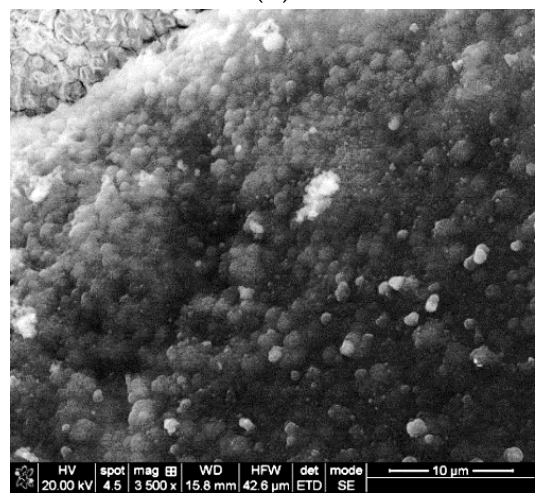

(e)

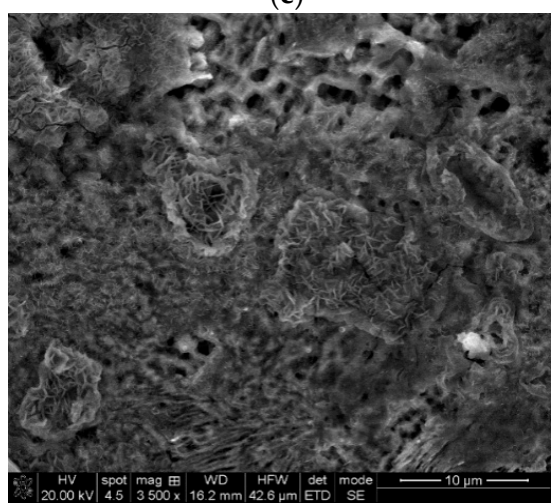

(h)

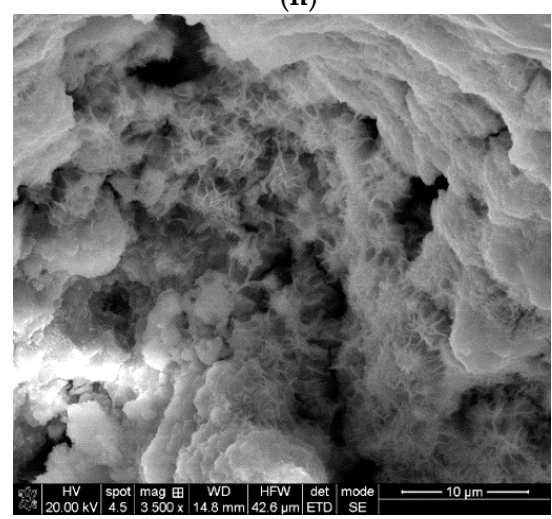

(j)

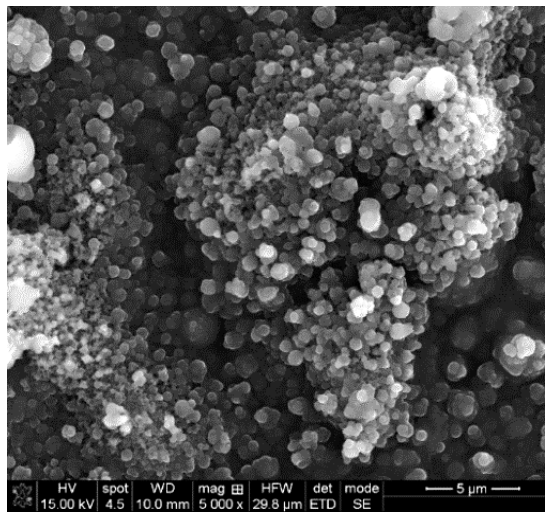

(c)

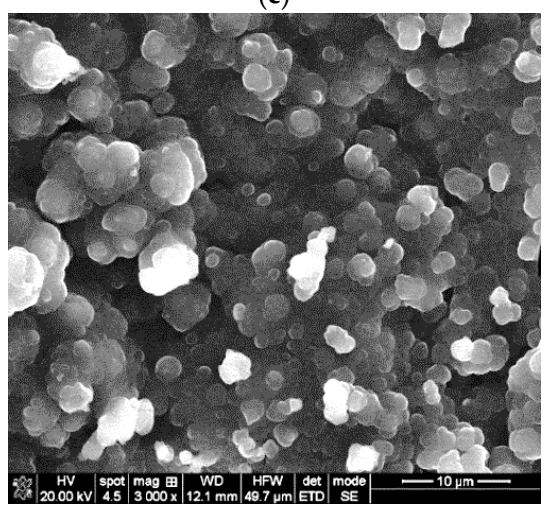

(f)

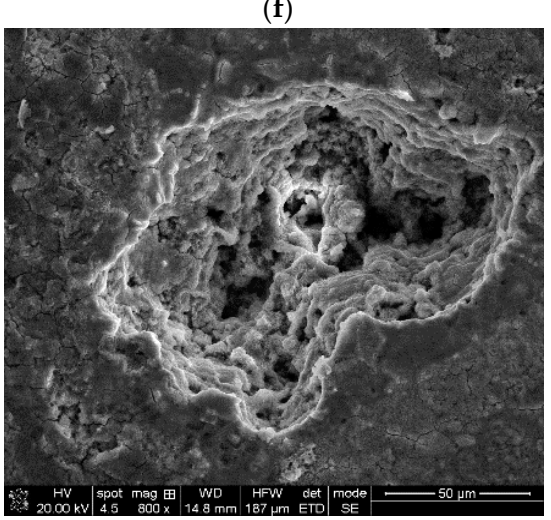

(i) 


\section{Conclusions}

The PNMPY-TRX100/PNNDEA composite coatings were successfully electrodeposited densely, uniformly, and adherent to an OL 37 electrode by galvanostatic technique at various current densities in oxalic acid solution. The electrochemical experiments prove that PNMPY-TRX100/PNNDEA behaves as an anticorrosion protective layer on OL 37 in $0.5 \mathrm{M} \mathrm{H}_{2} \mathrm{SO}_{4}$ solution, and the corrosion rate of this composite coated carbon steel is determined to be $\sim 9$ times less than that of uncoated carbon steel, and the protection performance of this composite coating is more than $90 \%$. FT-IR spectroscopic exploration suggests that the PNMPY-TRX100/PNNDEA composite polymer is formed over the OL 37 substrate and the SEM picture of PNMPY-TRX100/PNNDEA coating applied to OL 37 is homogeneous, is a strong adherent on the OL 37 surface, and the characteristic of the coating is of the highest quality.

The PNMPY-TRX100/PNNDEA coatings obtained at $5 \mathrm{~mA} / \mathrm{cm}^{2}$ current density in molar ratios of 5:1 and 3:2 NMPY-TRX100: NNDEA at $20 \mathrm{~min}$ and $30 \mathrm{~min}$ admitted and at $8 \mathrm{~mA} / \mathrm{cm}^{2}$ current density at molar ratios of 5:1 and 1:1 NMPY-TRX100: NNDEA at 30 min permitted the polymer to exhibit higher corrosion protection than at $3 \mathrm{~mA} / \mathrm{cm}^{2}$ current density in the same conditions. The corrosion protection characteristics follow the sequence: PNMPY-TRX100/PNNDEA at $5 \mathrm{~mA} / \mathrm{cm}^{2}>8 \mathrm{~mA} / \mathrm{cm}^{2}>3 \mathrm{~mA} / \mathrm{cm}^{2}$, because the presence of these coatings determines a substantial diminution in corrosion rate. It was evident that the composite coatings impede the attack of the aggressive element $\left(\mathrm{H}_{2} \mathrm{SO}_{4}\right)$ on the OL 37 substrate and the new composite PNMPY-TRX100/PNNDEA acquired by this technique is promising, and might lead to industrial practices in the protection of metals surfaces from corrosion.

Author Contributions: Conceptualization F.B.; methodology, investigation, resources, data curation, writing-original draft preparation, writing_review and editing F.B. and A.B.; investigation S.P. All authors have read and agreed to the published version of the manuscript.

Funding: This research received no external funding.

Institutional Review Board Statement: Not applicable.

Informed Consent Statement: Not applicable.

Data Availability Statement: Data is contained within the article.

Conflicts of Interest: The authors declare no conflict of interest.

\section{References}

1. Zhai, Y.; Pan, K.; Zhang, E. Anti-Corrosive Coating of Carbon-Steel Assisted by Polymer-Camphor sulfonic Acid Embedded within Graphene. Coatings 2020, 10, 879. [CrossRef]

2. Kumar Gupta, D.; Neupane, S.; Singh, S.; Karki, N.; Yadav, A.P. The effect of electrolytes on the coating of polyaniline on mild steel by electrochemical methods and its corrosion behavior. Prog. Org. Coat. 2021, 152, 106127. [CrossRef]

3. Gallegos-Melgar, A.; Serna, S.A.; Lázaro, I.; Gutiérrez-Castañeda, J.; Mercado-Lemus VArcos-Gutierrez, H.H.; HernándezHernández, M.; Porcayo-Calderón Jan Mayen, J.; Del Angel Monroy, M. Potentiodynamic Polarization Performance of a Novel Composite Coating System of A12O3/Chitosan-Sodium Alginate, Applied on an Aluminum AA6063 Alloy for Protection in a Chloride Ions Environment. Coatings 2020, 10, 45. [CrossRef]

4. Tavandashti, N.P.; Almas, S.M.; Esmaeilzadeh, E. Corrosion protection performance of epoxy coating containing alumina/PANI nanoparticles doped with cerium nitrate inhibitor on Al-2024 substrates. Prog. Org. Coat. 2021, 152, 106133. [CrossRef]

5. Li, J.; He, Y.; Sun, Y.; Zhang, X.; Shi, W.; Ge, D. Synthesis of Polypyrrole/V2O5 Composite Film on the Surface of Magnesium Using a Mild Vapor Phase Polymerization (VPP) Method for Corrosion Resistance. Coatings 2020, 10, 402. [CrossRef]

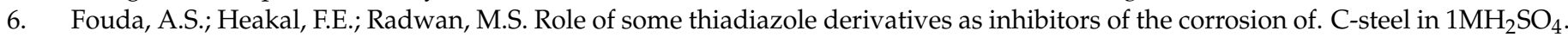
J. Appl. Electrochem. 2009, 39, 391-402. [CrossRef]

7. Asami, K.; Hashimoto, K. Importance of initial surface film in the degradation of stainless steels by atmospheric exposure. Corros. Sci. 2003, 45, 2263-2283. [CrossRef]

8. Aliyu, I.K.; Kumar, M.; Abdul Samad Mohammed, A. Wear and corrosion resistance performance of UHMWPE/GNPs nanocomposite coatings on AA2028 Al alloys. Prog. Org. Coat. 2021, 151, 106072. [CrossRef]

9. Cheng, L.; Wu, H.; Li, J.; Zhao, H.; Wang, L. Polydopamine modified ultrathin hydroxyapatite nanosheets for anti-corrosion reinforcement in polymeric coatings. Corros. Sci. 2021, 178, 10906. [CrossRef] 
10. Boshkova, N.; Kamburova, K.; Koprinarov, N.; Konstantinova, M.; Boshkov, N.; Radeva, T. Obtaining and Corrosion Performance of Composite Zinc Coatings with Incorporated Carbon Spheres. Coatings 2020, 10, 665. [CrossRef]

11. Liu, A.; Tian, H.; Li, S.; Xiaodan, J.; Yang, H.; Sun, Y.; Wang, L.; Li, W. Bioinspired layered hybrid coatings with greatly enhanced barrier effect and active corrosion protection performance. Prog. Org. Coat. 2021, 152, 106131. [CrossRef]

12. Ji, S.; Gui, H.; Guan, G.; Zhou, M.; Guo, Q.; Tan, M.Y. Molecular design and copolymerization to enhance the anti-corrosion performance of waterborne acrylic coatings. Prog. Org. Coat. 2021, 153, 106140. [CrossRef]

13. Branzoi, F.; Branzoi, V. Enzymatic electrode obtained by immobilizing of urease into a nanocomposite film based on conducting polymers and different additives. Int. J. Polym. Mater. Polym. Biomater. 2014, 63, 549-556. [CrossRef]

14. Yağan, A.; Pekmez, N.Ö.; Yıldız, A. Poly(N-methylaniline) coatings on stainless steel by electropolymerization. Corros. Sci. 2007, 49, 2905-2919. [CrossRef]

15. Branzoi, F.; Branzoi, V.; Pahom, Z. Monolayer and bilayer conducting polymer coatings for corrosion protection of copper in $5 \mathrm{M}$ $\mathrm{H}_{2} \mathrm{SO}_{4}$ solutions. Rev. Roum. Chim. 2013, 58, 49-58.

16. Rui, M.; Zhu, A. The synthesis and corrosion protection mechanisms of PANI/CNT nanocomposite doped with organic phosphoric acid. Prog. Org. Coat. 2021, 153, 106134. [CrossRef]

17. González, M.B.; Saidman, S.B. Electrodeposition of polypyrrole on 316L stainless steel for corrosion prevention. Corros. Sci. 2011, 53, 276-282. [CrossRef]

18. Herrasti, P.; Patil, P. Corrosion protective poly (o-ethoxyaniline) coatings on copper. Electrochim. Acta 2007, 53, 927-933.

19. Branzoi, F.; Branzoi, V. Investigation of Protective Effect of Polymeric Film Coatings on Carbon Steel in Aggressive Solutions. Int. J. Electrochem. Sci. 2016, 11, 6564-6579. [CrossRef]

20. Duran, B.; Turhan, M.C.; Bereket, G.; Sarac, A.S. Electropolymerization, characterization and corrosion performance of poly(Nethylaniline) on copper. Electrochim. Acta 2009, 55, 104-112. [CrossRef]

21. Yagan, A.; Pekmez, O.N.; Yildiz, A. Poly(N-ethylaniline) coatings on 304 stainless steel for corrosion protection in aqueous $\mathrm{HCl}$ and $\mathrm{Na}$ Clsolutions. Electrochim. Acta 2008, 53, 2474-2482. [CrossRef]

22. Shi, S.; Zhao, Y.; Zhang, Z.; Yu, L. Corrosion protection of a novel $\mathrm{SiO}_{2} @ P A N I$ coating for Q235 carbon steel. Prog. Org. Coat. 2019, 132, 227-234. [CrossRef]

23. Rajagopalan, R.; Iroh, J.O. Characterization of polyaniline-polypyrrole composite coatings on low carbon steel: A XPS and infrared spectroscopy study. Appl. Surf. Sci. 2003, 218, 58-69. [CrossRef]

24. Abdollah, O.; Hussein, R.; Razieh, M. Electrochemical synthesis of polypyrrole/polyhedral oligomeric silsesquioxane nanocomposite on copper for corrosion protection. Prog. Org. Coat. 2016, 90, 331-338.

25. Al Juhaiman, L.A. Polyvinyl pyrrolidone as a Corrosion Inhibitor for Carbon Steel in HCl. Int. J. Electrochem. Sci. 2016, 11, 1621-1631.

26. Yagan, A.; Pekmez Ozcicek, N.; Yildiz, A. Electrodeposition of poly(N-methyl aniline) on mildsteel: Synthesis, Characterization and corrosion protection. J. Electroanal. Chem. 2005, 578, 231-238. [CrossRef]

27. Branzoi, F.; Băran, A.; Ludmila, A.; Alexandrescu, E. The inhibition action of some organic polymers on the corrosion carbon steel in acidic media. Chem. Pap. 2020, 74, 4315-4335. [CrossRef]

28. Chaudhari, S.; Patil, P.P. Inhibition of steel corrosion by electrosynthesizedpoly(o-anisidine)-dodecylbenzenesulfonate coatings. Electrochim. Act. 2010, 55, 6715-6723. [CrossRef]

29. Hasanov, R.; Bilgic, S. Monolayer and bilayer conducting polymer coatings for corrosion protection of steel in $1 \mathrm{M} \mathrm{H}_{2} \mathrm{SO}_{4}$ solution. Prog. Org. Coat. 2009, 64, 435-445. [CrossRef]

30. Brânzoi, V.; Branzoi, F.; Pilan, L. Characterization of electrodeposited polymeric and composite modified electrodes on cobalt based alloy. Mater. Chem. Phys. 2009, 118, 197-202. [CrossRef]

31. Zeybek, B.; Pekmez, N.O.; Kilic, E. Electrochemical synthesis of bilayer coatings of poly(N-methylaniline) and polypyrrole on mild steel and their corrosion protection performances. Electrochim. Acta 2011, 56, 9277-9286. [CrossRef]

32. Branzoi, F.; Brânzoi, V.; Musina, A. Fabrication and characterisation of conducting composite films based on conducting polymers and functionalised carbon nanotubes. Surf. Interface Anal. 2012, 44, 1076-1080. [CrossRef]

33. Sazou, D.; Kourouzidou, M.; Pavlidou, E. Potentiodynamic and potentiostatic deposition of polyaniline on stainless steel: Electrochemical and structural studies for a potential application to corrosion control. Electrochim. Acta 2007, 52, 4385-4397. [CrossRef]

34. Branzoi, F.; Branzoi, V.; Musina, A. Coatings based on conducting polymers and functionalized carbon nanotubes obtained by electropolymerization. Prog. Org. Coat. 2013, 76, 632-638. [CrossRef]

35. Pekmez, N.O.; Cinkıllı, K.; Zeybek, B. The electrochemical copolymerization of pyrrole and bithiophene on stainless steel in the presence of SDS in aqueous medium and its anticorrosive performance. Prog. Org. Coat. 2014, 77, 1277-1287. [CrossRef]

36. Menkuer, M.; Ozkazanc, H. Anticorrosive polypyrrole/zirconium-oxide composite film prepared in oxalic acid and dodecylbenzene sulfonic acid mix electrolyte. Prog. Org. Coat. 2020, 147, 105815. [CrossRef] 